\title{
Working
}

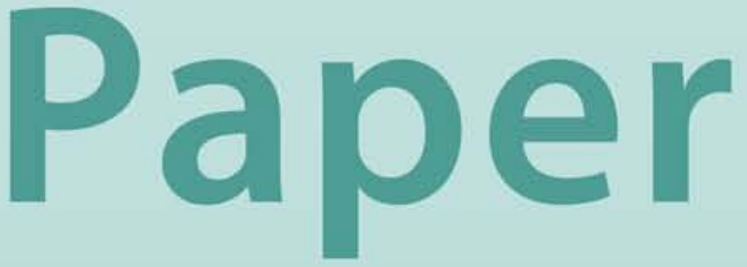




\section{Stock Market Liberalizations: Financial and Macroeconomic Implications}

Nicola Fuchs-Schündeln and Norbert Funke 


\title{
IMF Working Paper
}

\author{
IMF Institute
}

\section{Stock Market Liberalizations: Financial and Macroeconomic Implications}

\author{
Prepared by Nicola Fuchs-Schündeln and Norbert Funke ${ }^{1}$ \\ Authorized for distribution by Roland Daumont
}

December 2001

\begin{abstract}
The views expressed in this Working Paper are those of the author(s) and do not necessarily represent those of the IMF or IMF policy. Working Papers describe research in progress by the author(s) and are published to elicit comments and to further debate.
\end{abstract}

Using a panel of 27 countries, we analyze the effects of stock market liberalization on financial and macroeconomic development. We find that liberalization is associated with a short-term increase in real private investment growth of about 14 percentage points cumulatively in the four years following liberalization and a cumulative 4 percentage point increase in real GDP per capita growth. Growth tends to be higher if institutional reforms precede liberalization. In contrast to other studies, we also find evidence for a permanent growth effect of about 0.4 percent a year in an extended sample of 72 countries.

JEL Classification Numbers:F3, G1, O1

Keywords: Stock markets, financial liberalization, regulation

Author’s E-Mail Address:nicola.fuchs@yale.edu, nfunke@imf.org

\footnotetext{
' Nicola Fuchs-Schündeln is a Ph.D. student at Yale University and former Summer Intern at the IMF Insitute and Norbert Funke is an Economist at the IMF Institute. The authors thank Allan Brunner, Anne Epaulard, Andrew Feltenstein, Samir Jahjah, Donald Mathieson, Hyginus Leon, Eduardo Ley, Sunil Sharma, and seminar participants at the IMF Institute and at Yale University for helpful suggestions and stimulating comments on a preliminary draft. They are also thankful to Utpal Bhattacharya, Benoît Mercereau, and Ross Levine for providing them with their data sets on country credit rating, exchange rate regimes, and institutional developments.
} 
I. Introduction $\underline{3}$

II. Links Between Liberalization and Financial and Economic Development .......................... 4

A. Theoretical Considerations ….....................................................................

B. Overview of Empirical Analyses on Stock Market Liberalization ............................

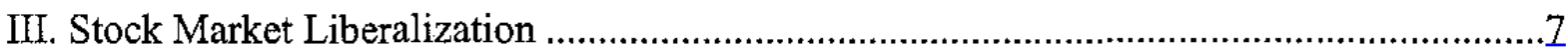

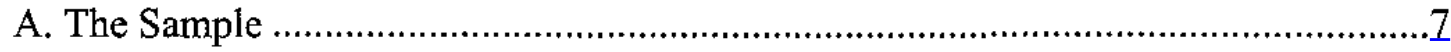

B. Choice of Liberalization Dates......................................................................

C. Economic Environment Prior to the Liberalization .............................................

IV. Implications of Stock Market Liberalizations: Empirical Analysis .................................12

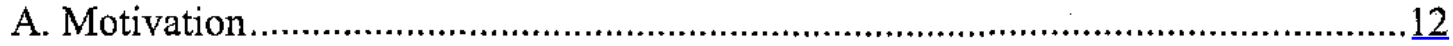

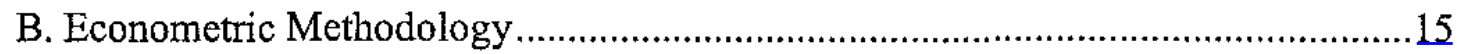

C. Impact on Stock Market Size and Liquidity..................................................16

D. Impact on Real Private Investment Growth ........................................................18

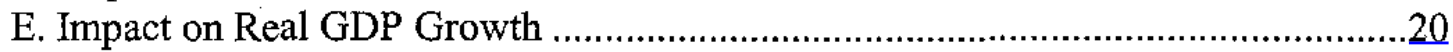

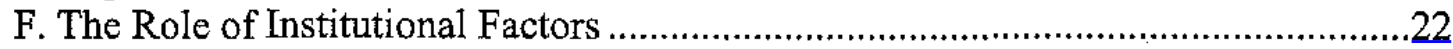

G. Liberalization Effect or Comprehensive Reforms? ……....................................26

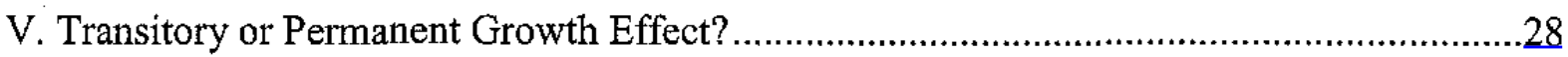

VI. Tentative Policy Conclusions ..............................................................................

Appendixes

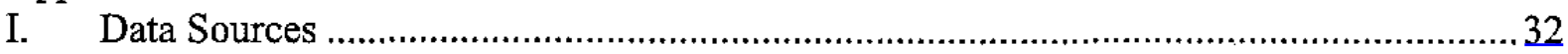

II. Stock Market Liberalization: Comparing Liberalization Dates ..................................34

III. Stock Market Liberalization: Stylized Development....................................................36

IV. Financial and Economic Development by Region........................................................37

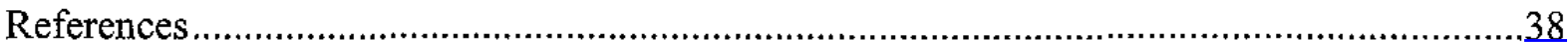

Tables

1. Stock Markets and Stock Market Liberalization: Basic Data .............................................

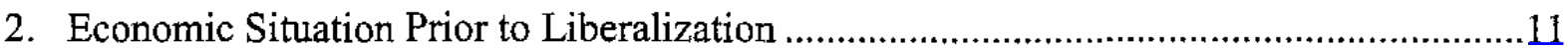

3. Financial and Macroeconomic Development Before and After Liberalization..................12

4. Stock Market Liberalization and Financial Development ............................................17

5. Stock Market Liberalization and Real Private Investment Growth .................................19

6. Stock Market Liberalization and Real GDP Growth per capita ......................................21

7. Stock Market Liberalization: Financial and Institutional Framework .............................24

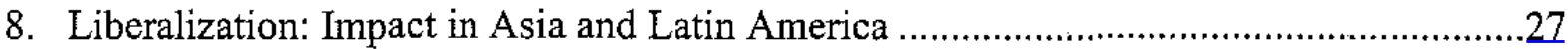

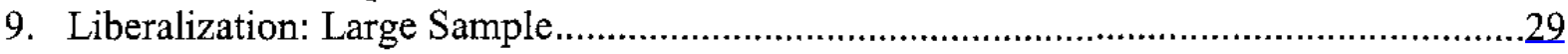

Figure 1. Stock Market Liberalization: Stylized Development ..........................................14 


\section{INTRODUCTION}

During the last two decades, many emerging markets have opened their domestic stock markets to foreign investors, but equity markets in some 50 countries remain largely closed to foreign participation. ${ }^{2}$ Permitting foreigners to buy stocks in the domestic stock market is one way of obtaining access to international equity capital. For countries that already have a stock market but have not yet (fully) liberalized their markets, important policy questions include: What are the implications of a stock market liberalization on financial development and general economic development? When and under what circumstances is it recommendable to liberalize the stock market? Are there any prerequisites for reaping the potential benefits of a market liberalization, for example, prerequisites related to initial economic conditions and institutional environment?

With these policy issues in mind, the aim of this paper is to offer an overview of existing findings and to provide new empirical evidence on the links between stock market liberalization, financial development, and economic development. This work is partially stimulated by Bekaert and Harvey (2000), Singal and Kim (2000), and Henry (2000a), who have looked at the financial implications of stock market liberalizations. It also draws on Bekaert, Harvey, Lundblad $(2000,2001)$ and Henry (2000b), who explore the implications of equity market liberalizations on investment and growth.

In a broader perspective, the analysis of the macroeconomic implications of stockmarket liberalizations relates to the research on capital account liberalization (see, e.g., IMF 2001). A stock market liberalization-a country's decision to allow foreigners to purchase domestic stocks-is a specific element of capital account liberalization as it removes restrictions on capital inflows and typically on capital outflows (e.g., repatriation of dividends, investment returns). A stock market liberalization is thus a particular type of policy that may help to promote financial and economic development. ${ }^{3}$

Compared with most previous analyses on this topic, we look closer at the three-way link between liberalization, financial development and economic development using a set of countries. This enables us to identify some of the channels through which the positive effects of stock market liberalization spread and to better understand the link between financial liberalization and real development. Taking into account other reforms, our estimated short-run growth effects on real private investment and real GDP per capita appear to offer a more coherent picture of the macroeconomic implications than those found in previous analyses. We

${ }^{2}$ See Bekaert, Harvey, Lundblad (2001), p. 11.

${ }^{3}$ For a general analysis of the linkages between financial development and growth, see for example, King and Levine (1993), Atje and Jovanovic (1993), Levine and Zervos (1998), and Rousseau and Wachtel (2000). Levine $(1997,1999)$ and Khan and Senhadji (2000) provide recent surveys of this literature. 
also show that the benefits of a liberalization are higher in countries that have improved their institutional framework prior to liberalization. Finally, in contrast to the few other analyses, we find support for a permanent growth effect associated with stock market liberalization of about 0.4 percent per annum.

Following this introduction, Section II gives a brief overview of theoretical considerations and recent empirical investigations on the effects of stock market liberalizations. Section III looks at major recent stock market liberalizations and the circumstances surrounding them. Section IV presents new empirical evidence. First, we analyze the interaction between stock market liberalization and stock market development. Then we look at the link between liberalization and real private investment growth as well as the link between liberalization and real GDP growth. We then assess the cross-country differences in the institutional environment to determine their impact on different outcomes across countries. Last, we perform a sensitivity analysis to assess whether the liberalization effect reflects other reform measures as well. In Section V, we extend the sample to include countries that had already liberalized their stock markets before the beginning of our sample period and countries that remain largely closed to foreign participation. We test the robustness of our previous results and reassess whether a stock market liberalization leads only to transitory or also to permanent growth effects. Section VI draws some broad policy conclusions.

\section{LinKs Between Liberalization and FinanCial and ECONOMIC DEVELOPMENT}

\section{A. Theoretical Considerations}

Well-functioning stock markets are expected to influence growth through increased capital accumulation and by influencing the efficiency of capital allocation (Levine 2001). Liberalization can stimulate capital accumulation because it will, under some plausible assumptions, reduce the cost of equity and, more generally, the aggregate cost of capital. This occurs because liberalization can reduce both components of the cost of equity, that is the riskfree rate and the equity premium. ${ }^{4}$ If the risk-free interest rate in the liberalizing country is higher than the world risk-free interest rate, the availability of additional foreign capital resulting from financial liberalization is likely to reduce the risk-free rate. Foreign participation in domestic equity markets will contribute to improved risk sharing and better risk allocation, thus reducing the equity premium. Also, higher market liquidity due to stock market liberalization may help reduce the risk premium. A reduction in the aggregate cost of capital stimulates capital accumulation, in particular real private investments, since some of the projects that were not profitable before are more likely to become profitable now. This in turn may be expected to have a positive effect on growth.

\footnotetext{
${ }^{4}$ See Henry (2000b) for a more detailed theoretical discussion of the underlying assumptions and their implications.
} 
In contrast to the capital accumulation argument, more recent work has highlighted the importance of factors that primarily influence the efficiency of capital allocation. Improved risk sharing and more liquid markets will also promote high return investments and longer-duration projects (e.g., Devereux and Smith (1994), Obstfeld (1994), Bencivenga, Smith, and Starr (1995)). Thus, improved risk sharing and more liquid markets improve the allocation of capital, and hence will stimulate productivity and growth. More liquid and well-developed markets also have a positive impact on the information-gathering behavior of private agents. Information theory suggests that it is easier to benefit from new information in more liquid and welldeveloped markets. Consequently, if stock market liberalization enhances liquidity, agents have a greater incentive to invest in information-gathering and researching firms (Holmstrom and Tirole, 1993 and Boot and Thakor, 1997). Better information about firms helps to improve the allocation of resources and again contributes to positive implications for growth.

Stock market liberalization may also improve corporate control. By allowing foreigners to buy domestic stocks, international scrutiny and performance pressure rise. This should directly or indirectly increase the quality, pricing, and the availability of products and services (Levine 2001). Better developed markets facilitate future takeovers, and therefore enhance managerial incentives to perform well and help to better align the incentives of managers and shareholders. This also improves resource allocation. These positive effects, however, are not undisputed. A liberalization that is associated with higher stock market returns may have an ambiguous effect on domestic savings, depending on the relative importance of the income and substitution effect. Also, Shleifer and Vishny (1986) have argued that increased market liquidity may weaken corporate governance by reducing the incentives for shareholders to monitor managers, which then might lead to a less efficient allocation of resources.

From a theoretical point of view it is an open question whether a stock market liberalization only has a temporary or a permanent effect on growth. On the one hand, a temporary increase of real GDP growth is consistent with a closed-economy Solow growth model. A stock market liberalization that reduces the cost of capital will lead to a higher steadystate level of capital. In the transition path to the new steady state, the growth rate of private investment will rise until the marginal product of capital corresponds to the new cost of capital and then the growth rate will drop back to the pre-liberalization rate. On the other hand, an improvement in efficiency and capital allocation may have a lasting impact on real per capita GDP growth.

\section{B. Overview of Empirical Analyses on Stock Market Liberalization}

The theoretical debate has stimulated a number of empirical analyses on the effects of stock market liberalization that fall into two categories. The first looks at the financial implications of stock market liberalizations, while the second looks at the real effects of liberalization. In most cases, these studies compare the development of crucial variables in the period prior to the market opening to the development of these variables after the market opening, controlling for changes in other developments. 
Empirical analyses on the financial implications of stock market liberalization tend to support theoretical predictions. Bekaert and Harvey (2000) confirm that in a sample of 20 emerging markets stock market liberalization promoted market integration and reduced the cost of equity capital. In a similar direction Henry (2000a) and Kim and Singal (2000) show that liberalization is accompanied by abnormal returns prior to and during actual reform implementation. The revaluation of the aggregate equity price index is associated with falling costs of equity. There is some evidence that the volatility of stock prices and other key macroeconomic variables rises in some cases during the liberalization period; however, there are no signs that the volatility of key macroeconomic variables increases systematically.

In terms of implications on real macroeconomic developments, Henry (2000b) analyses the effects of stock market liberalizations on private investment in a sample of 11 emerging markets. He finds a significant and very large transitory effect. The mean growth rate of real private investment exceeds the sample mean by 22 percentage points in the three years following liberalization. This positive relationship persists even after controlling for world business cycle effects, economic reforms, and domestic fundamentals.

Bekaert, Harvey and Lundblatt $(2000,2001)$ examine the relationship between official equity market liberalizations and real per capita GDP growth, employing different data samples. They use a General Methods of Moments estimator on panel data with overlapping observations from 1980 to 1997. The largest samples consist of 95 and 75 countries. Smaller samples, which include information on the general development of the equity market, include 50 countries and 28 liberalization cases. Overall, results suggest that equity market liberalizations, on average, lead to a one-percent increase in the annual growth rate of real GDP over a five-year period. The growth effect is not permanent. The transitory effect on growth is consistent with Henry's results on real private investment growth (Henry 2000b). Bekaert, Harvey and Lundblatt (2001) also examine potential transmission channels, cross-country differences in the liberalization effects, and the effect of liberalization on convergence. A central conclusion of their analysis is that stock market liberalization appears to provide an independent stimulus to growth. The effects of financial liberalizations are not fully captured by other variables commonly used in growth regressions. Liberalization effects are larger for countries with a larger secondary school enrollment, a small government sector, and an AngloSaxon legal system.

Existing results thus seem to indicate that equity market liberalizations are associated with transitory increases in the growth rate of real private investment and real GDP. However, a number of potential caveats have to be kept in mind. First, strictly speaking estimations reveal correlations and not necessarily causality. The analyses assume exogeneity of stock market liberalization decisions. Causality might run in the opposite direction. Politicians might decide to liberalize the stock market either when the economic environment is favorable or when it is perceived to become favorable. However, Henry (2000b) finds, for example, no evidence that past investment booms have an explanatory value for stock market liberalization. Beck and Levine (2001) present evidence that the relationship between financial development and growth is not due to potential simultaneity biases or omitted variables, but reflects the influence of stock markets and banks on economic growth. Second, despite the inclusion of control 
variables, the liberalization effect may still reflect other policy reforms and not only the effect of stock market liberalization.

Besides these general caveats, a number of more specific questions remain. The large effect on private investment is not necessarily incompatible with the estimated growth effects, but the enormous differences in magnitude appear to warrant further investigation. ${ }^{5}$ Also, all analyses only point to a transitory effect. Some theoretical analyses suggest that a successful liberalization should also have a permanent positive effect on growth. In addition, most of the analyses have given limited guidance to policymakers in countries where stock markets already exist but are not yet open to international investors. Answers to the questions of when, how and under what circumstances to liberalize are still vague and explanations of cross-country differences are only at a preliminary stage. Moreover, relatively little emphasis has thus far been put on the relation between equity market liberalization and financial development. The following empirical analysis addresses some of these issues.

\section{Stock Market Liberalization}

\section{A. The Sample}

Using annual data from 1975 to 2000 , we take a sample of 27 countries that liberalized their stock markets between 1980 and 1995 . We relied on information provided in the abovementioned recent studies, in particular, the detailed chronology from Bekaert and Harvey of important financial and political events. This chronology includes 22 of the 27 countries included into our study. ${ }^{6}$ In addition, we checked whether liberalization occurred during our sample period for other countries that are included in the Emerging Market Database of Standard \& Poors (formerly from the International Finance Corporation).

Our sample comprises 12 Asian, 7 Latin American, 5 African and 3 European countries. Seven of these countries are now part of the Organization for Economic Cooperation and

${ }^{5}$ On the one hand, these results may reflect specific developments special to the small sample of countries. On the other hand, they may indicate that resources were not necessarily efficiently allocated during the dramatic rise in private investment or that they omitted variables that are correlated with stock market liberalization drive the results.

${ }^{6}$ See http://www.duke.edu/ charvey/Country risk/chronology. For any liberalization after the mid-1990s, the post-liberalization period would be too short for a meaningful medium-term analysis. Central and Eastern Europen countries are not included in our study because stock markets in these countries only developped after the transformation process started, thus limiting the observation period. Also, in some cases, equity markets were open to foreign investments right from the beginning. For an analysis of developments in Central and Eastern Europe see Claessens, Djankov, and Klingebiel (2000). 
Development (OECD). Financial market data are taken mainly from the emerging market database. Most of the other data come either from the International Financial Statistics, the World Economic Outlook, or the World Development Indicators (see Appendix I).

\section{B. Choice of Liberalization Dates}

As with other segments of capital account liberalization, stock markets are often not fully liberalized at once. A number of countries with a domestic stock market initially allowed only very limited foreign participation. One way participation occurred was through a first (small) country fund. Narrow quantitative restrictions limiting foreign holdings to minority stakes in voting stocks were also common. In some cases these initial quantitative restrictions differed from sector to sector, with politically sensitive sectors receiving greater protection.

To evaluate the financial and macroeconomic impacts of stock market liberalizations, the dates of liberalization are crucial. The few empirical analyses available use different methods to identify dates of stock market liberalizations, depending on the exact nature and objective of the studies,. Typically, studies that look at the financial implications using highfrequency data focus on the first signs of liberalization. For those that look at the real implications, liberalizations must be significant enough to have verifiable real effects.

Henry $(2000 \mathrm{a}, \mathrm{b})$ identifies the date of a country's first stock market liberalization with a verifiable occurrence of any of the following three events: date of an official policy decree; the establishment of the first country fund; and an increase in the IFC's investability index, which measures the ratio of the market capitalization of stocks that foreigners can legally hold to total market capitalization, by at least 10 percent. But this third measure never actually occurs before any of the two others. Kim and Singal (2000) base their findings on different sources and press searches to explain the liberalization steps taken in each country. Bekaert and Harvey (2000, 2001 ) focus on official liberalizations. Though in a number of cases the selected liberalization dates coincide, in other cases they differ depending on the methods (see Appendix II for an overview). ${ }^{7}$

We focus on official liberalization dates, which in most cases are the dates of the official policy decree. In determining the dates, we have given special attention to countries for which the existing studies used different liberalization dates and to countries that were included in only one or two of the studies. In the latter cases we based our decision on additional information from the respective stock exchanges, national authorities, and sources such as the Economist Intelligence Unit country reports. For these countries, we explain our information and sources in the note to Table 10 in the Appendix II.

\footnotetext{
${ }^{7}$ In contrast to these measures, Edison and Warnock (2001) look more specifically at the evolution of the degree of restrictions on foreign ownership of equities over time.
} 
We also cross-checked all the liberalization dates with information on equity flows provided in the World Development Indicators of the World Bank. In all cases equity flows into the country started from a zero level in the year prior to the liberalization or equity flows rose significantly around the date of the official liberalization from a more negligible level before.

\section{Economic Environment Prior to the Liberalization}

Table 1 provides some basic information on the development of the stock markets in our sample: the year of the establishment of the stock market, the liberalization year, and general information on the size of the market. Market size is described by the number of companies listed and market capitalization, which is the value of listed shares in the domestic stock exchange. For comparison, we also indicate the size of the banking sector, measured in terms of credit to the private sector as a share of GDP. By and large, the overview indicates that stock markets in most countries under consideration have reached a noticeable size. In all but five countries, stock market capitalization exceeds 20 percent of GDP, a level that roughly corresponds to the average of countries in the euro area in 1990 (1990: 22 percent of GDP, 1999: 84 percent of GDP, see World Development Indicators 2001)

Table 1. Stock Markets and Stock Market Liberalization: Basic Data

\begin{tabular}{|c|c|c|c|c|c|c|}
\hline & Establishment & $\begin{array}{l}\text { Stock market } \\
\text { liberalization }\end{array}$ & $\begin{array}{l}\text { No. of } \\
\text { companies } \\
(2000)\end{array}$ & $\begin{array}{l}\text { Market } \\
\text { Capitalization in } \\
\text { bn. US\$ }(2000)\end{array}$ & $\begin{array}{l}\text { Market Cap in } \\
\% \text { GDP } \\
(2000)\end{array}$ & $\begin{array}{c}\text { Private Credit } \\
\text { in } \% \text { GDP-last } \\
\text { available }\end{array}$ \\
\hline Argentina & 1854 & 1989 & 127 & 166.1 & 58.2 & 23.8 \\
\hline Brazil & 1890 & 1991 & 459 & 226.2 & 40.9 & 34.5 \\
\hline Chile & 1893 & 1992 & 258 & 60.4 & 91.7 & 68.0 \\
\hline Colombia & 1928 & 1991 & 126 & 9.6 & 12.4 & 27.1 \\
\hline Egypt & 1890 & 1993 & 1076 & 28.7 & 34.0 & 59.7 \\
\hline Greece & 1876 & 1986 & 329 & 110.9 & 95.4 & 53.3 \\
\hline India & 1875 & 1992 & 5937 & 148.1 & 32.6 & 25.8 \\
\hline Indonesia & 1912 & 1989 & 290 & 26.8 & 20.1 & 20.9 \\
\hline Japan & 1878 & 1980 & 2096 & 3193.9 & 71.1 & 115.3 \\
\hline Jordan & 1978 & 1995 & 163 & 4.9 & 59.3 & 71.0 \\
\hline Korea & 1956 & 1992 & 704 & 148.7 & 36.3 & 101.9 \\
\hline Malaysia & 1973 & 1988 & 795 & 116.9 & 130.9 & 136.0 \\
\hline Mexico & 1894 & 1989 & 179 & 125.2 & 22.1 & 13.5 \\
\hline Morocco & 1929 & 1994 & 53 & 10.9 & 32.6 & 54.5 \\
\hline Nigeria & 1960 & 1995 & 195 & 4.2 & 11.2 & 13.8 \\
\hline Pakistan & 1947 & 1991 & 762 & 6.6 & 11.3 & 29.5 \\
\hline Peru & 1951 & 1991 & 230 & 10.6 & 19.7 & 26.2 \\
\hline Philippines & 1927 & 1991 & 230 & 51.6 & 77.5 & 44.2 \\
\hline Portugal & 1825 & 1986 & 110 & 60.7 & 56.7 & 102.6 \\
\hline South Africa & 1887 & 1995 & 616 & 204.9 & 177.8 & 137.2 \\
\hline Spain & 1831 & 1985 & 1036 & 504.2 & 88.6 & 92.5 \\
\hline Sri Lanka & 1896 & 1990 & 239 & 1.1 & 7.0 & 24.6 \\
\hline Taiwan (China) & 1961 & $199 \mathrm{I}$ & 531 & 247.6 & 84.5 & n.a. \\
\hline Thailand & 1974 & 1987 & 381 & 29.5 & 26.1 & 109.0 \\
\hline Turkey & 1866 & 1989 & 315 & 69.7 & 37.3 & 23.2 \\
\hline Venezuela & 1840 & 1990 & 85 & 8.1 & 6.9 & 12.1 \\
\hline Zimbabwe & 1896 & 1993 & 69 & 2.4 & 41.8 & 27.2 \\
\hline
\end{tabular}

Sources: Bhattacharya and Daouk (2001), Standard \& Poors, Intenational Federation of Stock Exchanges, IMF, World Bank. 
In a number of countries stock market liberalization did not take place in isolation but was part of larger reforms. In particular, in some countries the stock market was liberalized only after stabilization measures had been implemented and some trade reforms initiated (Henry 2000b). Table 2 documents the macroeconomic environment in the period leading up to the liberalization, for example, the inflationary environment, the extent of stabilization efforts, real growth, and the level and change of trade integration in the world economy prior to liberalization. The last column, change in credit rating, serves as an overall proxy for changes in the economic and political environment prior to liberalization (see also, for example, Bhattacharya and Daouk, 2001). The credit rating refers to the rating of the Institutional Investor, in which leading private sector economists grade each country other than their home country on a scale of zero to 100 , with 100 representing countries that have the least chance of default. Evaluations reflect changes in a broad range of policies; an improvement in the rating thus indicates a general improvement in the economic situation or the credibility of the authorities' efforts. The number of asterisks $\left({ }^{* * *}\right)$ is intended to show the economic environment: the more stars, the more favorable the initial situation or the more positive the changes in the period prior to the liberalization. Though the categorization of the economic situation is arguably somewhat arbitrary, the table is nonetheless helpful in gauging the initial situation.

In terms of stabilization, most of the countries liberalized their stock markets at a time when inflation was largely under control or was falling because of stabilization efforts. In terms of real growth developments, the situation was mixed. In roughly half of the countries, real growth in the liberalization year was lower than in preceding years. More clear-cut results emerge for the case of trade integration. In roughly two-thirds of the countries, increased integration of the domestic economy in the world economy occurred prior to liberalization, at least partially reflecting some trade reforms in the years before the stock market liberalization. A closer look at credit ratings confirms that the economic situation in most countries was assessed to be reasonably sound. This overview thus provides indirect evidence that stock market liberalization was integrated into larger reform efforts. In line with theoretical insights from the sequencing literature, the stock market liberalization, as one specific element of a capital account liberalization, occurred either simultaneously or after the implementation of other reform efforts. ${ }^{8}$

${ }^{8}$ On sequencing of reforms, see for example, Funke (1993), Johnston (1998), Johnston and Sundararajan (1999), and Nsouli and Rached (1998). 
Table 2: Economic Situation Prior to Liberalization

\begin{tabular}{|c|c|c|c|c|c|c|c|}
\hline & $\begin{array}{c}\text { Low } \\
\text { inflation } \\
\text { l/ }\end{array}$ & $\begin{array}{c}\text { Inflation } \\
\text { reduction/ } \\
\text { stabilization } \\
2 / \\
\end{array}$ & $\begin{array}{l}\text { Change in } \\
\text { GDP } \\
\text { Growth } \\
3 /\end{array}$ & $\begin{array}{c}\text { Openness } \\
4 / \\
\end{array}$ & $\begin{array}{c}\text { Change in } \\
\text { Openness } \\
5 / \\
\end{array}$ & $\begin{array}{c}\text { Credit rating } \\
6 / \\
\end{array}$ & $\begin{array}{c}\text { Change } \\
\text { in Credit } \\
\text { Rating } \\
7 / \\
\end{array}$ \\
\hline Argentina & - & - & - & - & $* *$ & 21 & m \\
\hline Brazil & - & $* * *$ & - & - & - & 27 & - \\
\hline Chile & $*$ & $* *$ & $* *$ & $* *$ & - & 45 & $* \pi *$ \\
\hline Colombia & - & - & - & $*$ & $*$ & 36 & - \\
\hline Egypt & * & $* *$ & $* *$ & $* *$ & - & 27 & $* *$ \\
\hline Greece & * & $*$ & * & $*$ & - & 48 & - \\
\hline India & * & - & - & - & * & 38 & - \\
\hline Indonesia & * & - & $* *$ & * & * & 45 & - \\
\hline Japan & $* * * t$ & $* *$ & $* * *$ & - & ** & 95 & - \\
\hline Jordan & $* * *$ & - & - & $* * *$ & $*$ & 27 & $* *$ \\
\hline Korea & $* *$ & - & - & $* *$ & - & 68 & $* *$ \\
\hline Malaysia & $* * *$ & - & $* * *$ & $* * *$ & $* * *$ & 55 & - \\
\hline Mexico & - & $* * *$ & $* *$ & $\cdots *$ & $* *$ & 30 & - \\
\hline Morocco & $* * *$ & $*$ & $* * *$ & $* *$ & - & 37 & $* * *$ \\
\hline Nigeria & - & - & - & $* * *$ & * & 17 & - \\
\hline Pakistan & $* * *$ & $* *$ & * & * & * & 28 & - \\
\hline Peru & - & $* * *$ & $* *$ & - & - & 12 & - \\
\hline Philippines & * & - & - & $* *$ & $* *$ & 25 & * \\
\hline Portugal & * & * & $* *$ & $* *$ & - & 51 & - \\
\hline South Africa & * & * & ** & $*$ & * & 44 & $* *$ \\
\hline Spain & * & $*$ & $* *$ & * & * & 66 & - \\
\hline Sri Lanika & * & - & $* *$ & $* *$ & $* *$ & 22 & - \\
\hline Taiwan (China) & $* * * *$ & - & - & $* * *$ & - & 77 & * \\
\hline Thailand & $* * *$ & - & ** & $* *$ & **t & 54 & $*$ \\
\hline Turkey & - & - & - & $*$ & * & 41 & $* *$ \\
\hline Venezuela & - & - & $* * *$ & $* *$ & $* * *$ & 32 & - \\
\hline Zimbabwe & * & - & - & $* *$ & $* * *$ & 27 & $*$ \\
\hline
\end{tabular}

1/ Inflation is measured by the GDP deflator in the year of the liberalization: inflation below $5 \%\left({ }^{* * *}\right)$, inflation between $5 \%$ and $10 \%\left({ }^{* *}\right)$, and inflation below $25 \%(*)$. - indicates that inflation was above $25 \%$.

$2 /$ The rate of inflation in the year of the liberalization compared with the average of the five years before liberalization. Drop in inflation by more than 1 percentage point $(*)$, between 5 and 10 percentage points $\left({ }^{* *}\right)$ and by more than 10 percentage points $(* * *)$. - indicates an increase in inflation or a drop below $1 \%$.

$3 /$ Change in real GDP per capita growth between the year of liberalization and the average of the five years before liberalization: above $4 \%\left({ }^{* * *}\right)$, between $1 \%$ and $4 \%\left({ }^{* *}\right)$, and between $0 \%$ and $1 \%\left({ }^{*}\right)$. - indicates a negative change

4/ Openness is measured by the ratio of exports and imports of goods and services over GDP in the year of liberalization if the ratio exceeds $80 \%\left({ }^{* * *}\right)$, between $50 \%$ and $80 \%\left({ }^{* *}\right)$, and between $30 \%$ and $50 \%\left({ }^{*}\right)$. - indicates a lower openness.

5 / The change in openness compares the ratio of trade/GDP in the year of the liberalization to the five-year average of the years prior to liberalization: an increase between 0 and 5 percentage points (*), between 5 and 10 percentage points $\left({ }^{* *}\right)$, and above 10 percentage points $(* * *)$. - indicates a decrease in the openness, still the country can be fairly open.

6/ The credit rating refers to the rating of the Institutional Investor, ranging from a scale of 0 to 100 , with 100 representing the countries with the least chance of default

7/ Comparison of change in credit rating in the year of the liberalization with the average of the five years before. An increase by more than 5 percentage points $\left({ }^{* *}\right)$, between 2 and 5 percentage points $\left({ }^{*}\right)$, and up to 2 percentage points $\left({ }^{*}\right)$. - no increase or a decline. 


\section{IMPlications of StOCK MARKET LIBERAlizations: EMPIRICAL ANALYSIS}

\section{A. Motivation}

To determine whether stock market liberalization produces positive effects, we must ultimately observe its effect on economic growth. To better understand the mechanisms behind the liberalization effects, we focus on two potential channels through which liberalization can foster growth, namely its impact on domestic stock market development and its subsequent impact on real private investment. Following Demirgüç-Kunt and Levine (1996), Levine and Zervos (1998) and others, we use three indicators to measure the development of the stock market: market capitalization, number of listed companies, and the turnover ratio. The latter is defined here as the value of turnover divided by market capitalization. Stock market liberalization and development should foster private investment growth. In the end, through increased stock market development and private investment growth, the growth rate of real GDP per capita is expected to rise after stock market liberalization. Table 3 provides a first indication that stock market liberalization stimulates stock market development, real investment growth, and, ultimately, real GDP growth.

Table 3: Financial and Macroeconomic Development Before and After Liberalization (In percent)

\begin{tabular}{lcccc}
\hline & $\begin{array}{c}\text { Average 3 Years } \\
\text { Before } \\
\text { Liberalization }\end{array}$ & $\begin{array}{c}\text { Liberalization } \\
\text { Year }\end{array}$ & $\begin{array}{c}\text { Average 3 Years } \\
\text { After Liberalization }\end{array}$ & $\begin{array}{c}\text { Increases } 1 / \\
\text { Out of Total }\end{array}$ \\
\hline $\begin{array}{l}\text { Financial Markets } \\
\text { Market Cap /GDP growth }\end{array}$ & 3.3 & & & \\
$\begin{array}{l}\text { Number of listed companies growth } \\
\text { Tumover ratio growth }\end{array}$ & 3.4 & 25.9 & 9.0 & $18 / 25$ \\
Real Effects & -4.6 & 56.7 & 11.7 & $17 / 23$ \\
Real private investment growth & 2.7 & 3.1 & 12.1 & $19 / 25$ \\
Real per capita GDP growth & 0.8 & 2.5 & 8.7 & $18 / 27$ \\
\hline
\end{tabular}

\footnotetext{
${ }^{1}$ Shows the number of countries in which the average growth rate of the respective variable in the year of liberalization and the three subsequent years is higher than in the four years before liberalization (sample used for each variable varies depending on data availability)
}

Results show that the growth rate of market capitalization and turnover ratio increase significantly in the liberalization year and exhibit a higher average in the three years following liberalization than in the three years before liberalization. The average annual increase in the number of listed companies also rises significantly after liberalization. The growth rates of real private investment and real per capita GDP are higher after the liberalization than before the liberalization, although the effect on real private investment is more pronounced. To confirm that our results are not driven by a few outliers, the last column identifies the number of countries for which the average growth rate of the respective variable was higher in the period after liberalization compared with the pre-liberalization average. Indeed, for most variables there exist only some outliers, amounting to less than a third of the sample. Therefore, Table 3 
provides first evidence that stock market liberalization might indeed lead to positive growth effects.

To show the dynamics of the development of key variables around the time of a stock market liberalization, Figure 1 (panels a-f) plots the average growth rates of the corresponding variables around the liberalization period. In each case, $t$ is the year of stock market liberalization for every country, $t-5$ depicts the situation five years before liberalization, and $t+5$ the situation five years after liberalization. For example, the value on the $y$-axis corresponding to the $x$-axis value of $t$, is the average growth rate of the respective variable across all countries in our sample in the respective year of liberalization. The growth rate is expressed as log differences, thus multiplying the value on $y$-axis by 100 gives the growth rate in percent.

Figure 1 confirms previous findings and provides additional insights. Clearly, stock market liberalization is accompanied by an increase in the size and liquidity of the market (Figure 1a-c). The largest impact occurs quickly and the impact appears to dissipate over time.' Real private investment also exhibits growth rates of more than 10 percent in the three years following the stock market liberalization (Figure 1d). ${ }^{10}$ However, in contrast to the effects on the development of domestic stock markets, it appears to take some time before the maximum effect materializes. Real per capita GDP growth rates also exhibit an upward trend after liberalization, peaking at shortly below 4 percent (Figure 1e). However, five years before liberalization they actually reach values of almost five percent. A closer inspection of the data suggests that these high growth rates may be related to the "Asian miracle" of the 1980s.

${ }^{9}$ Appendix III shows the same graphs with standard errors. It shows considerable country variability in the growth rates of the stock market variables. However, the standard errors do not increase during the time of liberalization, which may suggest an important growth effect from liberalization on the stock market characteristics.

${ }^{10}$ Figure 1 (panels $\mathrm{d}$ and f on real private investment) include only 25 countries (except Zimbabwe and Nigeria). In both countries, real private investment growth was extremely volatile, reflecting the effects of periods associated with large political uncertainties. The inclusion of both countries, however, does not change the general shape and the timing of the effects. 
Figure 1. Stock Market Liberalization: Stylized Development
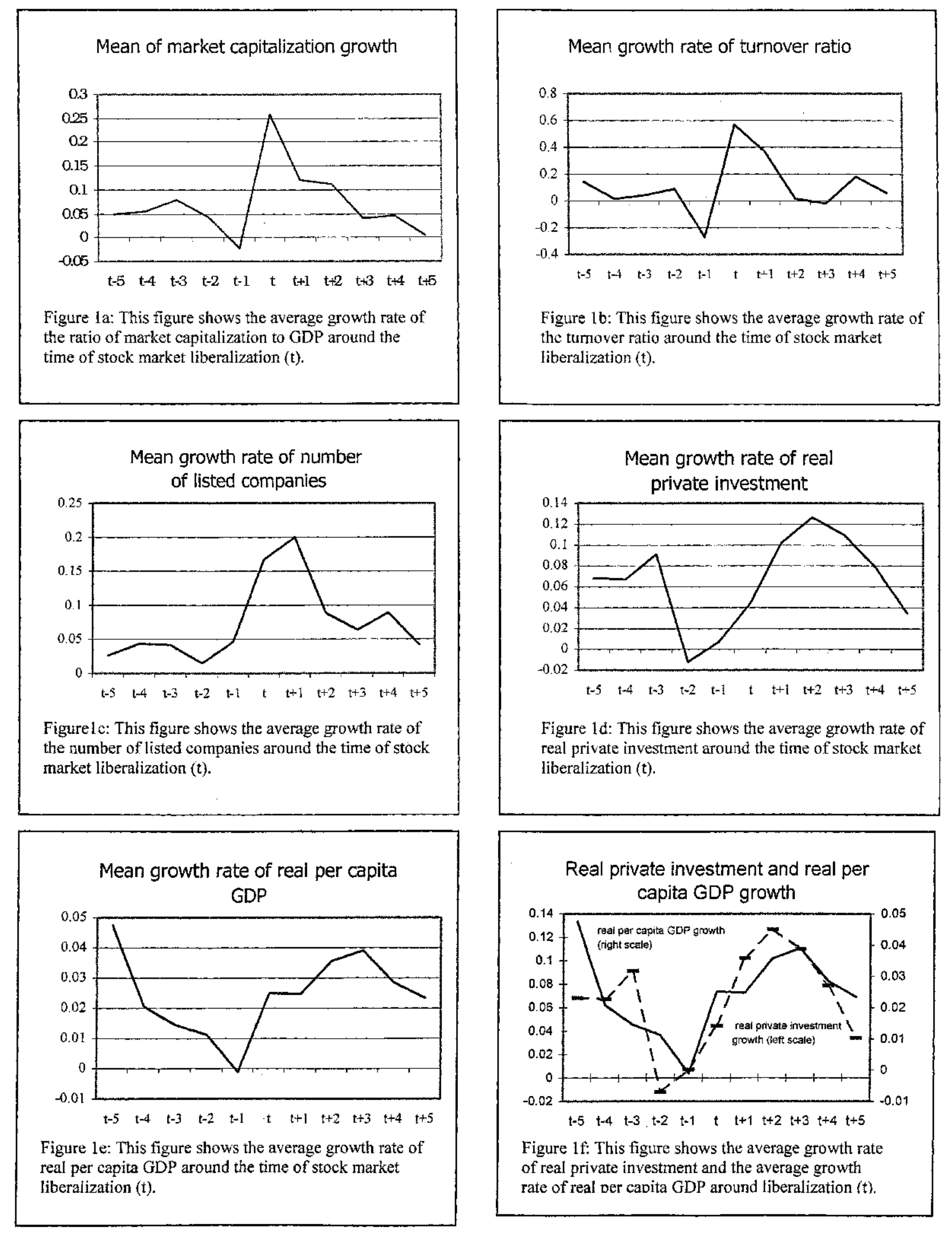
Finally, Figure 1(f) suggests that the growth rate of real private investment follows a similar pattern as the growth rate of real per capita GDP, but with a lead of up to one year. Overall, the timing suggests that stock market development and real growth of private investment may be two interrelated channels that contribute to higher GDP growth. The effect of the liberalization on stock market development seems immediate, whereas the real effects are larger given a reasonable lack of a few years.

Based on these promising findings, we continue with an econometric analysis in order to assess the significance of the various impacts, to better understand the underlying dynamics, and to make sure that we are not detecting spurious relationships.

\section{B. Econometric Methodology}

In the econometric analysis, we use panel data estimation with annual variables. As we are also interested in the dynamics of the adjustment process, we create the dummy variables $l i b$, which takes on the value 1 in the year of liberalization and 0 in each other year, postlib1, which takes on the value 1 in the first year after liberalization and 0 in each other year, postlib 2 and so on. If we were only interested in long-term effects, it would be sufficient to include a dummy variable $l i b a l l$, which would take on the value 1 in the year of liberalization and all years afterwards and then to test for its significance. However, apart from our interest in short-term dynamics, the dummy liball has proven insignificant in the majority of our estimates. Still, it may be that in our sample of 27 countries, with a number of liberalizations in the $1990 \mathrm{~s}$, the remaining observation period is too short to detect a long-run effect. We will return to the question of whether there are permanent real growth effects in Section V. At this stage, a closer analysis of the data in our sample suggests that the effects generally fade away after a maximum of four years, we thus include post-liberalization dummies up to year five.

In each section we estimate a variant of the following regression:

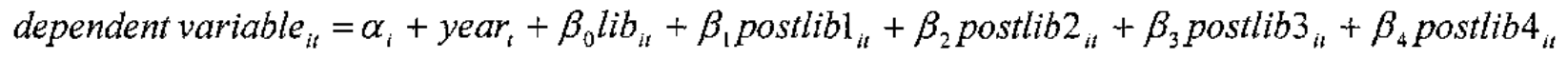
$+\beta_{s}$ postlib $_{i t}+\gamma^{\prime}$ controls $_{i t}+\varepsilon_{i t}$

In the following, the dependent variable (dependent variable $i$ ) refers either to one of the three stock market development indicators, the real rate of growth of private investment or real GDP growth per capita. The index i refers to the country and tenotes the time period. Using panel data allows us to include cross-sectional fixed effects $\left(\alpha_{i}\right)$ and thus to mitigate any potential omitted variable bias. Since we are not primarily interested in explaining the sources for the development of the dependent variable per se, but the effects of liberalization on this variable, this is very helpful. Moreover, we include year dummies for every year to account for world business cycle effects or other special worldwide effects (e.g., oil price shock). Last, special controls suggested by theory and controls for other reform measures are used in each of the regressions. If liberalization has a positive effect on the respective dependent variable, we should see positive and significant $\beta$-coefficients. If the effect.is temporary, the coefficients should become insignificant eventually. 
We follow Henry (2000b) and use feasible GLS to account for possible cross-section heteroskedasticity in the error term. ${ }^{11}$ The weights are based on the estimated cross-section. residual variances from a first stage pooled OLS regression. We use White's heteroskedasticity consistent covariance estimates. This variance estimator is robust to heteroskedasticity within each cross-section. In all estimations, we use the unbalanced sample.

\section{Impact on Stock Market Size and Liquidity}

To test for the significance of the link between stock market liberalization and financial development, we regress each of the three stock market variables on the liberalization dummies, year dummies, and fixed effects (Table 4).

The dummy for the liberalization year is positive and significant in all four cases. Stock market liberalization seems to have an immediate, significant positive effect on the growth rates of market capitalization, turnover ratio, and number of listed companies, and hence, is favorable for stock market size and liquidity.

Liberalization has an immediate positive effect of 40 percentage points on market capitalization growth and of 32 percentage points on turnover ratio growth. A closer analysis of the growth rate of the market capitalization in the post liberalization period suggests that an important part of the effect is related to a revaluation of equity prices. ${ }^{12}$ This is consistent with the observed smaller but significant increase in the growth rate of the number of listed companies.

In terms of dynamics, the effect of stock market liberalization on the growth rate of market capitalization shows a declining pattern and is dying out in the fourth year after liberalization. The pattern for the growth rate of the turnover ratio is similar, yet with an insignificant effect in the second year after liberalization. In contrast, the growth rate of the number of listed companies peaks in the fourth year after liberalization at 4.7 percentage points.

\footnotetext{
${ }^{11}$ For a discussion of alternative estimation techniques, see Hansen and Tarp (2001); Haque, Pesaran, and Sharma (1999); among others.

${ }^{12}$ We regressed the total return index growth on the liberalization dummies, country fixed effects, and year dummies. Liberalization also has an impact on equity prices up to the fourth year after the liberalization, but the cumulative impact amounted only to about 75 percent of the cumulative impact on market capitalization growth.
} 
Table 4. Stock Market Liberalization and Financial Development

\begin{tabular}{|c|c|c|c|}
\hline & $\begin{array}{l}\text { Market capitalization } \\
\text { growth }\end{array}$ & $\begin{array}{c}\text { Growth in number of listed } \\
\text { companies }\end{array}$ & Turnover ratio growth \\
\hline $\mathrm{Lib}$ & $\begin{array}{l}0.3996^{* * *} \\
(0.0721) \\
(0.000)\end{array}$ & $\begin{array}{l}0.0217^{*} \\
(0.0116) \\
(0.063)\end{array}$ & $\begin{array}{l}0.3148^{* * * *} \\
(0.1016) \\
(0.002)\end{array}$ \\
\hline Postlib I & $\begin{array}{l}0.2082^{* * *} \\
(0.0580) \\
(0.000)\end{array}$ & $\begin{array}{l}0.0429 * * * \\
(0.0129) \\
(0.001)\end{array}$ & $\begin{array}{l}0.2811^{* * *} \\
(0.0705) \\
(0.000)\end{array}$ \\
\hline Postlib2 & $\begin{array}{l}0.1332 * * * \\
(0.0478) \\
(0.006)\end{array}$ & $\begin{array}{l}0.0357^{* * *} \\
(0.0095) \\
(0.000)\end{array}$ & $\begin{array}{l}-0.0566 \\
(0.0458) \\
(0.217)\end{array}$ \\
\hline Postlib3 & $\begin{array}{l}0.0964^{* * * *} \\
(0.0337) \\
(0.004)\end{array}$ & $\begin{array}{l}0.0314 * * * \\
(0.0057) \\
(0.000)\end{array}$ & $\begin{array}{l}0.2034^{* * * *} \\
(0.0689) \\
(0.003)\end{array}$ \\
\hline Postlib4 & $\begin{array}{l}0.0564 \\
(0.0444) \\
(0.204)\end{array}$ & $\begin{array}{l}0.0473 * * * \\
(0.0057) \\
(0.000)\end{array}$ & $\begin{array}{l}0.0098 \\
(0.0691) \\
(0.888)\end{array}$ \\
\hline Postlib5 & $\begin{array}{l}0.0568 \\
(0.0391) \\
(0.148)\end{array}$ & $\begin{array}{l}0.0159^{* * * *} \\
(0.0058) \\
(0.007)\end{array}$ & $\begin{array}{l}-0.0193 \\
(0.0578) \\
(0.739)\end{array}$ \\
\hline Adj. $R^{2}$ & 0.20 & 0.30 & 0.10 \\
\hline
\end{tabular}

Note: Market capitalization growth is the change in the logarithm of market capitalization over GDP. Growth in the number of listed companies and in the turnover ratio is the change in the logarithms. All regressions include country fixed effects and year dummies. The sample in the regression of turnover ratio growth only starts in 1977. Values in parentheses are standard errors and p-values.

*** significant at the $1 \%$ significance level.

** significant at the $5 \%$ significance level.

* significant at the $10 \%$ significance level.

The very immediate and large positive reaction of the stock market characteristics on liberalization might indicate that the decision to liberalize the stock market was anticipated by domestic participants. Around half of the liberalizations actually took place in the second half of the year, sometimes as late as December. In this case, actual participation of foreign investors in the stock market can only have been limited in the liberalization year. The stock market looks more attractive to domestic investors that anticipate liberalization.

The associated $R^{2}$ for the three estimations is rather low, which is not surprising given that we omit any controls except country fixed effects and year dummies, and given the low 
predictability of stock market variables. Still the results are striking enough to tell us that the influence of stock market liberalization on the overall stock market development is positive.

\section{Impact on Real Private Investment Growth}

To analyze the link between liberalization and real private investment growth, we perform four different regressions. The first and second estimations largely follow Henry $(2000 \mathrm{~b})$. In the first specification, we simply regress private investment growth on the liberalization dummies, country specific constants and year dummies. The second specification includes lagged GDP growth and the change in terms of trade as controls. Since we saw that in some countries stock market liberalization was part of a larger economic reform program, the third specification explicitly tries to control for other policy reforms. To control for stabilization efforts, we include inflation into the regression. To take account of potential effects of trade liberalization, we use trade openness, that is, the ratio of exports plus imports over GDP, as a proxy for trade liberalization. If trade liberalization is effectively implemented, it should lead to an increase in trade flows. In the fourth regression we include the change in the credit rating of a country. Arguably, the rating variable may be endogenous and may be highly correlated with other reform variables or with expected GDP. Still, we include the variable to potentially capture the overall effect of many possible economic reforms. Our main conclusions do not depend on this variable, nor were they affected when we included the rating variable without the other two variables that capture policy reforms. Thus, we interpret the inclusion of the rating variable as an additional robustness test.

Table 5 shows the results of our econometric analysis. Most variables have the expected sign and most are significant. The first regression indicates that private investment growth is significantly higher in the first four years after liberalization. Hence, it seems that there is at least a temporary positive effect of stock market liberalization on real private investment growth. In the second estimation, the liberalization effect on private investment growth still remains significant, but becomes smaller. After including the controls for policy reforms in the third and fourth regression, the effect of stock market liberalization on private investment growth again tends to become smaller.

In all specifications, the effect of stock market liberalization on private investment growth is hump-shaped and dies out in the fifth year after liberalization. The peak of the effect occurs in the second year after liberalization, when private investment growth increases by about 6.0 percentage points according to the most conservative estimate and by 7.5 percentage points according to the most optimistic one. The cumulative effect of stock market liberalization on private investment growth in the liberalization year and the three years following liberalization amounts to about 25 percentage points in the simplest regression and about 14 percentage points in the regression trying to control for other reforms.

These effects are much smaller than those estimated by Henry (2000b) for a sample of

11 countries using a similar method. In his basic regression, which resembles our first 
Table 5. Stock Market Liberalization and Real Private Investment Growth

\begin{tabular}{|c|c|c|c|c|}
\hline & (i) & (ii) & (iii) & (iv) \\
\hline Lib & $\begin{array}{l}-0.0078 \\
(0.0138) \\
(0.575)\end{array}$ & $\begin{array}{l}0.0059 \\
(0.0139) \\
(0.672)\end{array}$ & $\begin{array}{l}0.0076 \\
(0.0136) \\
(0.575)\end{array}$ & $\begin{array}{l}-0.0022 \\
(0.0137) \\
(0.871)\end{array}$ \\
\hline Postlibl & $\begin{array}{l}0.0648^{* * *} \\
(0.0135) \\
(0.000)\end{array}$ & $\begin{array}{l}0.0532^{* * * *} \\
(0.0131) \\
(0.000)\end{array}$ & $\begin{array}{l}0.0546 * * * \\
(0.0125) \\
(0.000)\end{array}$ & $\begin{array}{l}0.0419^{* * * *} \\
(0.0126) \\
(0.001)\end{array}$ \\
\hline Postlib2 & $\begin{array}{l}0.0751 * * * \\
(0.0127) \\
(0.000)\end{array}$ & $\begin{array}{l}0.0724 * * * \\
(0.0124) \\
(0.000)\end{array}$ & $\begin{array}{l}0.0755^{* * *} \\
(0.0130) \\
(0.000)\end{array}$ & $\begin{array}{l}0.0601 * * * \\
(0.0127) \\
(0.000)\end{array}$ \\
\hline Postlib3 & $\begin{array}{l}0.0626 * * * \\
(0.0170) \\
(0.000)\end{array}$ & $\begin{array}{l}0.0561 * * * \\
(0.0158) \\
(0.000)\end{array}$ & $\begin{array}{l}0.0598^{* * *} \\
(0.0158) \\
(0.000)\end{array}$ & $\begin{array}{l}0.0431 * * * \\
(0.0156) \\
(0.006)\end{array}$ \\
\hline Postlib4 & $\begin{array}{l}0.0564^{* * *} \\
(0.0179) \\
(0.002)\end{array}$ & $\begin{array}{l}0.0405^{* *} \\
(0.0178) \\
(0.024)\end{array}$ & $\begin{array}{l}0.0368^{* *} \\
(0.0177) \\
(0.038)\end{array}$ & $\begin{array}{l}0.0207 \\
(0.0162) \\
(0.204)\end{array}$ \\
\hline Postlib5 & $\begin{array}{l}0.0077 \\
(0.0172) \\
(0.654)\end{array}$ & $\begin{array}{l}0.0005 \\
(0.0174) \\
(0.979)\end{array}$ & $\begin{array}{l}-0.0009 \\
(0.0174) \\
(0.959)\end{array}$ & $\begin{array}{l}-0.0033 \\
(0.0184) \\
(0.857)\end{array}$ \\
\hline GDP growth (-1) & & $\begin{array}{l}0.6306^{* * *} \\
(0.2222) \\
(0.005)\end{array}$ & $\begin{array}{l}0.4809 * * \\
(0.2323) \\
(0.039)\end{array}$ & $\begin{array}{l}0.3000 \\
(0.1986) \\
(0.132)\end{array}$ \\
\hline Terms of trade growth & & $\begin{array}{l}0.1175^{* *} \\
(0.0476) \\
(0.014)\end{array}$ & $\begin{array}{l}-0.1216^{* * *} \\
(0.0481) \\
(0.012)\end{array}$ & $\begin{array}{l}0.1085^{* *} \\
(0.0543) \\
(0.047)\end{array}$ \\
\hline Trade openness & & & $\begin{array}{l}0.0245 \\
(0.0455) \\
(0.592)\end{array}$ & $\begin{array}{l}0.0359 \\
(0.0496) \\
(0.470)\end{array}$ \\
\hline Inflation & & & $\begin{array}{l}-0.0545^{* * * *} \\
(0.0166) \\
(0.001)\end{array}$ & $\begin{array}{l}-0.0451 * * * \\
(0.0161) \\
(0.006)\end{array}$ \\
\hline Change in credit rating & & & & $\begin{array}{l}0.4368 * * * \\
(0.0757) \\
(0.000)\end{array}$ \\
\hline Adj. $R^{2}$ & 0.11 & 0.14 & 0.15 & 0.20 \\
\hline
\end{tabular}

Note: The dependent variable is real private investment growth, measured as the change in the logarithm of real private investment. GDP growth is the change in the logarithm of real GDP per capita, and it is taken with one lag. Terms of trade growth is the change in the logarithm of terms of trade. Stock market size is the logarithm of the ratio of market capitalization to GDP. Trade openness is the value of exports plus imports over GDP. Inflation is the change in the logarithm of the consumer price index. Change in credit rating is the change in the logarithm of country credit rating. All regressions include country fixed effects and year dummies. The sample comprises 27 countries. Regression (i) includes 25 observations, regression (ii) and (iii) 24 observations, and (iv) 20 observations. Values in parentheses are standard errors and p-values. 
regression, liberalization raises the mean of private investment growth by almost 30 percentage points in the second year alone, and cumulatively by about 60 percentage points. However, a cumulative rise in the growth rate of private investment by about 14 percentage points is already a significant real effect, and we believe that our more modest results for a larger set of countries better reflects average developments.

\section{E. Impact on Real GDP Growth}

Finally, we analyze the effect of stock market liberalization on real GDP growth. For the growth regression, we retain our econometric methodology. Hence, in contrast to traditional growth regressions, we do not build five-year averages to eliminate business cycle effects. The inclusion of year dummies allows us to account for world business cycle effects, but not for country-specific business cycle effects. Compared with simple cross-sectional growth regressions, the panel estimation permits the inclusion of fixed effects and hence the alleviation of omitted variable biases.

As before, we run different regressions. In the first specification in Table 6 (i), we simply regress real GDP per capita growth on the liberalization dummies, country specific constants, and year dummies. The second estimation includes four variables that are commonly used in growth regressions, namely investment to GDP, ${ }^{13}$ population growth, a measure for human capital and a measure for financial development (see, for example, Barro 1997). ${ }^{14}$ The third specification (iii) again tries to capture the impact of other reform efforts.

${ }^{13}$ Levine and Renelt (1992) have shown that investment to GDP is the most robust explanatory variable in growth regressions. Since we showed in the previous section that real private investment growth is stimulated by liberalization, it could be argued that investment to GDP would capture an important part of the liberalization effect and thus drive out the liberalization effect. Results barely change when we drop this variable. Three reasons may account for this. First, investment to GDP also includes public investment, which in some emerging economies plays an important role and is highly variable. Second, whereas we looked at growth rates in the previous section, a level variable is included here. Third, an analysis of the correlation confirmed a positive but only weak link. In our sample, the correlation between private investment to GDP and investment to GDP is on average 0.56 percent and correlations between real private investment growth and investment to GDP is 0.21 .

${ }^{14}$ Due to time-series data availability we use illiteracy as a measure of human capital instead of the more frequently used secondary school enrollment. As before, we use market capitalization over GDP as proxy for financial development. 
Table 6. Stock Market Liberalization and Real GDP Growth per Capita

\begin{tabular}{|c|c|c|c|c|c|}
\hline & (i) & (ii) & (iii) & (iv) & (v) \\
\hline Lib & $\begin{array}{l}0.0129^{* * *} \\
(0.0035) \\
(0.000)\end{array}$ & $\begin{array}{l}0.0135^{* * *} \\
(0.0035) \\
(0.000)\end{array}$ & $\begin{array}{l}0.0132^{* * *} \\
(0.0034) \\
(0.000)\end{array}$ & $\begin{array}{l}0.0108^{* * *} \\
(0.0029) \\
(0.000)\end{array}$ & $\begin{array}{l}0.0020 \\
(0.0025) \\
(0.417)\end{array}$ \\
\hline Postlib I & $\begin{array}{l}0.0101^{* * *} \\
(0.0035) \\
(0.004)\end{array}$ & $\begin{array}{l}0.0109^{* * *} \\
(0.0029) \\
(0.000)\end{array}$ & $\begin{array}{l}0.0076^{* * *} \\
(0.0028) \\
(0.008)\end{array}$ & $\begin{array}{l}0.0031 \\
(0.0025) \\
(0.208)\end{array}$ & $\begin{array}{l}0.0011 \\
(0.0023) \\
(0.637)\end{array}$ \\
\hline Postlib2 & $\begin{array}{l}0.0167^{* * *} \\
(0.0029) \\
(0.000)\end{array}$ & $\begin{array}{l}0.0127 * * * \\
(0.0030) \\
(0.000)\end{array}$ & $\begin{array}{l}0.0082^{* *} \\
(0.0032) \\
(0.011)\end{array}$ & $\begin{array}{l}0.0043^{*} \\
(0.0025) \\
(0.078)\end{array}$ & $\begin{array}{l}0.0010 \\
(0.0019) \\
(0.607)\end{array}$ \\
\hline Postlib3 & $\begin{array}{l}0.0213^{* * *} \\
(0.0031) \\
(0.000)\end{array}$ & $\begin{array}{l}0.0161^{* * * *} \\
(0.0028) \\
(0.000)\end{array}$ & $\begin{array}{l}0.0095 * * * \\
(0.0026) \\
(0.000)\end{array}$ & $\begin{array}{l}0.0116^{* * *} \\
(0.0029) \\
(0.000)\end{array}$ & $\begin{array}{l}0.0064^{* *} \\
(0.0028) \\
(0.021)\end{array}$ \\
\hline Postlib4 & $\begin{array}{l}0.0115^{* * *} \\
(0.0031) \\
(0.000)\end{array}$ & $\begin{array}{l}0.0059 * * \\
(0.0025) \\
(0.021)\end{array}$ & $\begin{array}{l}-0.0014 \\
(0.0026) \\
(0.563)\end{array}$ & $\begin{array}{l}-0.0052^{* *} \\
(0.0025) \\
(0.038)\end{array}$ & $\begin{array}{l}0.0008 \\
(0.0024) \\
(0.729)\end{array}$ \\
\hline Postlib5 & $\begin{array}{l}0.0048 \\
(0.0031) \\
(0.117)\end{array}$ & $\begin{array}{l}0.0007 \\
(0.0032) \\
(0.823)\end{array}$ & $\begin{array}{l}-0.0023 \\
(0.0031) \\
(0.483)\end{array}$ & $\begin{array}{l}-0.0016 \\
(0.0034) \\
(0.647)\end{array}$ & $\begin{array}{l}-0.0007 \\
(0.0034) \\
(0.830)\end{array}$ \\
\hline I/Y & & $\begin{array}{l}0.2093 * * * \\
(0.0384) \\
(0.000)\end{array}$ & $\begin{array}{l}0.2460^{* * *} \\
(0.0412) \\
(0.000)\end{array}$ & $\begin{array}{l}0.1397^{* * * *} \\
(0.0378) \\
(0.000)\end{array}$ & $\begin{array}{l}0.1435 * * * * \\
(0.0373) \\
(0.000)\end{array}$ \\
\hline $\begin{array}{l}\text { Population } \\
\text { growth }\end{array}$ & & $\begin{array}{l}-0.4029^{* * *} \\
(0.0872) \\
(0.000)\end{array}$ & $\begin{array}{l}-0.3407^{* * *} \\
(0.0933) \\
(0.000)\end{array}$ & $\begin{array}{l}-0.4161 \\
(0.0782) \\
(0.000)\end{array}$ & $\begin{array}{c}-0.2494^{* * *} \\
(0.0915) \\
(0.007)\end{array}$ \\
\hline Illiteracy & & $\begin{array}{c}0.0000 \\
(0.0005) \\
(0.930)\end{array}$ & $\begin{array}{l}0.0000 \\
(0.0005) \\
(0.902)\end{array}$ & $\begin{array}{l}-0.0001 \\
(0.0006) \\
(0.820)\end{array}$ & $\begin{array}{l}-0.0003 \\
(0.0006) \\
(0.591)\end{array}$ \\
\hline $\begin{array}{l}\text { Stock market } \\
\text { size }\end{array}$ & & $\begin{array}{l}0.0075^{* * *} \\
(0.0014) \\
(0.000)\end{array}$ & $\begin{array}{l}0.0077^{* * *} \\
(0.0015) \\
(0.000)\end{array}$ & $\begin{array}{l}0.0064^{* * *} \\
(0.0014) \\
(0.000)\end{array}$ & $\begin{array}{l}0.0051^{* * *} \\
(0.0015) \\
(0.001)\end{array}$ \\
\hline Trade openness & & & $\begin{array}{l}-0.0015 \\
(0.0170) \\
(0.928)\end{array}$ & $\begin{array}{l}0.0086 \\
(0.0129) \\
(0.509)\end{array}$ & $\begin{array}{l}0.0092 \\
(0.0124) \\
(0.456)\end{array}$ \\
\hline Inflation & & & $\begin{array}{l}-0.0169^{* * *} \\
(0.0046) \\
(0.000)\end{array}$ & $\begin{array}{l}-0.0164^{* * *} \\
(0.0035) \\
(0.000)\end{array}$ & $\begin{array}{c}-0.0128 * * * \\
(0.0038) \\
(0.001)\end{array}$ \\
\hline $\begin{array}{l}\text { Change in credit } \\
\text { rating }\end{array}$ & & & $\begin{array}{l}0.1147^{* * *} \\
(0.0200) \\
(0.000)\end{array}$ & $\begin{array}{l}0.0743 * * * \\
(0.0183) \\
(0.000)\end{array}$ & $\begin{array}{l}0.0834 * * * \\
(0.0181) \\
(0.000)\end{array}$ \\
\hline $\begin{array}{l}\text { Real private } \\
\text { Investment } \\
\text { Growth }\end{array}$ & & & & $\begin{array}{l}0.0905^{* * *} \\
(0.0129) \\
(0.000)\end{array}$ & $\begin{array}{l}0.0901 * * * \\
(0.0124) \\
(0.000)\end{array}$ \\
\hline $\begin{array}{l}\text { Stock Market } \\
\text { Growth }\end{array}$ & & & & & $\begin{array}{l}0.0071^{* * * *} \\
(0.0025) \\
(0.005)\end{array}$ \\
\hline Adj. $R^{2}$ & 0.39 & 0.40 & 0.48 & 0.66 & 0.65 \\
\hline
\end{tabular}

Note: The dependent variable is the growth rate of real GDP per capita in local currency. I/Y is the ratio of investment to GDP. Population growth is the growth rate of the overall population, and illiteracy is the percentage of the population aged 15 to 24 who cannot read or write. All other variables are as explained in previous tables. All regressions include country fixed effects and year dummies. Due to data availability, the sample size of the regressions vary. Regressions (i) includes the full sample ( 27 countries and 25 observations), regression (ii) 26 countries (missing Taiwan (China)) and 25 observations and regressions (iii), (iv) and (v) 26 countries and 20 observations and regression. Values in parentheses are standard errors and p-values. 
The regression results confirm a positive temporary effect of stock market liberalization on real GDP growth. This effect is very robust to the inclusion of different controls. The positive effect is hump-shaped and peaks in the third year after liberalization. As in the regressions of private investment growth, the growth effects of liberalization diminish as we include controls for other policy reforms but they remain highly significant throughout. Even the conservative estimates hint at a cumulative growth effect of almost 4 percentage points in the year of liberalization and the following three years, that is, at an average growth effect of one percentage point during the first four years.

The $\mathrm{R}^{2}$ values in all of our growth regressions are reasonable compared with values in standard growth regressions. A visual inspection of the residuals points against serial autocorrelation in most countries' error terms.

The magnitude of our growth effects is similar to the one found by Bekaert, Harvey, and Lundblad (2001). Moreover, our estimates of the liberalization effects on real private investment growth and real GDP per capita growth draw quite a coherent picture: in the optimistic estimates, the effect on real private investment growth peaks at about 7.5 percentage points in the second year after liberalization, when the effect on real GDP per capita growth peaks at about 2 percentage points one year later. In the conservative estimates, real private investment growth peaks at 6.0 percentage points, and GDP growth at 1.3 percentage points.

To gauge whether real private investment plays an important role in the transmission of the liberalization effect, we explicitly include real private investment growth in the fourth estimation (iv). Importantly, this reduces the direct liberalization effect to about 2 percentage points cumulatively compared with a cumulative increase of about 4 percent before. One interpretation is that around 50 percent of the liberalization effect can be attributed to the beneficial effects on real private investment. Moreover, after including stock market growth, the liberalization effect falls to 0.6 percent in the third year, suggesting that more than 80 percent of the liberalization effect can be attributed to the beneficial effects on real private investment and financial development. Overall, the results appear consistent with the view that liberalization induces stock market development which in turn fosters private investment, which then stimulates growth.

\section{F. The Role of Institutional Factors}

Our analysis indicates significant positive effects of stock market liberalization on the development of the stock market, on private investment growth, and, ultimately, on GDP growth. But it may be that the positive effect of liberalization materializes only under certain circumstances or is more pronounced when certain preconditions are fulfilled. One could imagine, for example, that a very illiquid or very small stock market would be unattractive to foreign investors and that, in either case, liberalization might not lead to any effect. In addition, the institutional and macroeconomic environment could also influence the consequences of stock market liberalization. For example, foreign investors might favor stock markets in countries with a well-developed legal system or countries with less exchange rate volatility. 
From a policy perspective, it is therefore useful to evaluate the effects of stock market liberalization on growth under different circumstances. If stock market liberalization shows the largest growth effects only under certain preconditions, then a country that does not yet meet those conditions may prefer to wait and work on establishing the required prerequisites before turning its attention to stock market liberalization. In this regard, Bekaert, Harvey, and Lundblad (2001) present evidence that high secondary school enrollment, a small government sector, and an Anglo-Saxon legal system enhance the positive effects of liberalization.

We also analyze the effects of liberalization on GDP growth taking into account the specific situation or specific developments in the period before liberalization. To that end, we run the following regression to determine whether a certain level of a respective explanatory variable at the time of liberalization enhances the positive growth effect:

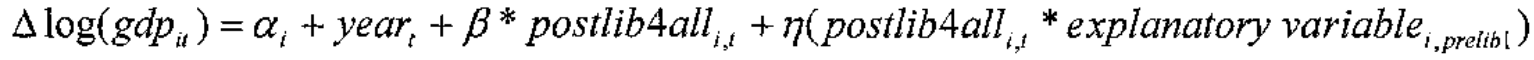

$$
\begin{aligned}
& +\sum_{k=0}^{4} \lambda_{k} * \text { explanatory variable }{ }_{i, t-k}+\delta^{\prime} \text { controls }_{i t}+\varepsilon_{i t}
\end{aligned}
$$

To focus on the interaction between the initial situation and the outcome, we no longer determine the different effects in each year. To this end, we create a new dummy variable postlib 4 all that takes on the value of 1 in the year of liberalization and the subsequent four years, and the value of 0 otherwise. Prelib1 denotes the year before liberalization. By interacting postlib4all ${ }_{i, t}$ with the specific situation prior to liberalization (explanatory variable enrelib $_{1}$ ), we create a variable that takes on the value of the explanatory variable before liberalization in the year of liberalization and the subsequent four years. A positive and significant $\eta$ coefficient would lead us to conclude that the positive growth effects of stock market liberalization are more pronounced if the explanatory variable takes on a favorable value in the year before liberalization. We include four lags of the explanatory variable to make sure that a significant $\eta$ coefficient captures a joint effect together with liberalization and is not an independent effect of the explanatory variable on future economic growth that can also arise in the absence of liberalization. The lags are mostly insignificant and we do not present them in our table below. As before, the $\beta$-coefficient captures the liberalization effect on growth that arises independently from any preconditions.

We assessed the importance of several possible preconditions for liberalization that belong to the categories of stock market characteristics, institutional environment and macroeconomic environment. We report the results in Table 7 for stock market size in columns (i) and (ii), for contract enforceability in columns (iii) and (iv), and for nationalization risk in columns (v) and (vi). 
Table 7. Stock Market Liberalization: Financial and Institutional Framework

\begin{tabular}{|c|c|c|c|c|c|c|}
\hline & \multicolumn{2}{|c|}{ Stock Market Size } & \multicolumn{2}{|c|}{ Contract Enforceability } & \multicolumn{2}{|c|}{ Nationalization Risk } \\
\hline & (i) & (ii) & (iii) & (iv) & (v) & (vi) \\
\hline Postlib4all & $\begin{array}{l}-0.0012 \\
(0.0028) \\
(0.675)\end{array}$ & $\begin{array}{l}-0.0011 \\
(0.0027) \\
(0.692)\end{array}$ & $\begin{array}{l}0.0124^{* * *} \\
(0.0027) \\
(0.000)\end{array}$ & $\begin{array}{l}0.0107 * * * \\
(0.0024) \\
(0.000)\end{array}$ & $\begin{array}{l}0.0100^{* * *} \\
(0.0015) \\
(0.000)\end{array}$ & $\begin{array}{l}0.0060^{* * * *} \\
(0.0016) \\
(0.000)\end{array}$ \\
\hline $\begin{array}{l}\text { Postlib4all and stock } \\
\text { market size before } \\
\text { liberalization }\end{array}$ & $\begin{array}{l}0.0286^{* *} \\
(0.0122) \\
(0.019)\end{array}$ & $\begin{array}{l}0.0197^{*} \\
(0.0116) \\
(0.091)\end{array}$ & & & & \\
\hline $\begin{array}{l}\text { Postlib4all and change } \\
\text { in contract } \\
\text { enforceability before } \\
\text { liberalization }\end{array}$ & & & $\begin{array}{l}0.1590^{*} \\
(0.0908) \\
(0.081)\end{array}$ & $\begin{array}{l}0.2667 * * * \\
(0.0904) \\
(0.003)\end{array}$ & & \\
\hline $\begin{array}{l}\text { Postlib4all and change } \\
\text { in nationalization risk } \\
\text { before liberalization }\end{array}$ & & & & & $\begin{array}{l}0.1310^{*} \\
(0.0702) \\
(0.063)\end{array}$ & $\begin{array}{l}0.1041 \\
(0.0651) \\
(0.111)\end{array}$ \\
\hline $\begin{array}{l}\text { Change in contract } \\
\text { enforceability }\end{array}$ & & & $\begin{array}{l}0.0380^{* *} \\
(0.0155) \\
(0.015)\end{array}$ & $\begin{array}{l}0.0227 \\
(0.0166) \\
(0.172)\end{array}$ & & \\
\hline $\begin{array}{l}\text { Change in } \\
\text { nationalization risk }\end{array}$ & & & & & $\begin{array}{l}0.0362^{* *} \\
(0.0163) \\
(0.027)\end{array}$ & $\begin{array}{l}0.0069 \\
(0.0199) \\
(0.728)\end{array}$ \\
\hline $\mathrm{U} / \mathrm{Y}$ & $\begin{array}{l}0.1292^{* * *} \\
(0.0030) \\
(0.000)\end{array}$ & $\begin{array}{l}0.0955^{* * *} \\
(0.0230) \\
(0.000)\end{array}$ & $\begin{array}{l}0.0684^{* * *} \\
(0.0210) \\
(0.001)\end{array}$ & $\begin{array}{l}0.0490^{* * *} \\
(0.0162) \\
(0.003)\end{array}$ & $\begin{array}{l}0.0824 * * * \\
(0.0226) \\
(0.000)\end{array}$ & $\begin{array}{l}0.0658^{* * *} \\
(0.0180) \\
(0.000)\end{array}$ \\
\hline Population growth & $\begin{array}{l}-0.3910^{* * *} \\
(0.090 \mathrm{~L}) \\
(0.000)\end{array}$ & $\begin{array}{l}-0.3873^{* * * *} \\
(0.0985) \\
(0.000)\end{array}$ & $\begin{array}{l}-0.4286^{* * *} \\
(0.1161) \\
(0.000)\end{array}$ & $\begin{array}{l}-0.4521 * * * \\
(0.1493) \\
(0.003)\end{array}$ & $\begin{array}{l}-0.4513^{* * *} \\
(0.1384) \\
(0.001)\end{array}$ & $\begin{array}{l}-0.4492^{* * *} \\
(0.1606) \\
(0.006)\end{array}$ \\
\hline Stock market size & $\begin{array}{l}0.0147^{* * *} \\
(0.0032) \\
(0.000)\end{array}$ & $\begin{array}{l}0.0125^{* * *} \\
(0.0029) \\
(0.000)\end{array}$ & $\begin{array}{l}0.0094^{* * *} \\
(0.0012) \\
(0.000)\end{array}$ & $\begin{array}{l}0.0069 * * * \\
(0.0012) \\
(0.000)\end{array}$ & $\begin{array}{l}0.0097^{* * * *} \\
(0.0009) \\
(0.000)\end{array}$ & $\begin{array}{l}0.0067^{* * *} \\
(0.0009) \\
(0.000)\end{array}$ \\
\hline Trade openness & & $\begin{array}{l}0.0202 \\
(0.0157) \\
(0.198)\end{array}$ & & $\begin{array}{l}0.0545^{* * *} \\
(0.0109) \\
(0.000)\end{array}$ & & $\begin{array}{l}0.0410^{\text {**** }} \\
(0.0098) \\
(0.000)\end{array}$ \\
\hline Inflation & & $\begin{array}{l}-0.0148^{* * * *} \\
(0.0048) \\
(0.002)\end{array}$ & & $\begin{array}{l}-0.0219^{* * *} \\
(0.0078) \\
(0.006)\end{array}$ & & $\begin{array}{l}-0.0218^{* * * *} \\
(0.0082) \\
(0.008)\end{array}$ \\
\hline Change in credit rating & & $\begin{array}{l}0.1002^{* * *} \\
(0.0205) \\
(0.000)\end{array}$ & & $\begin{array}{l}0.1078^{* * * *} \\
(0.0246) \\
(0.000)\end{array}$ & & $\begin{array}{l}0.1103^{* * *} \\
(0.0251) \\
(0.000)\end{array}$ \\
\hline $\operatorname{Adj} \cdot \mathbf{R}^{2}$ & 0.44 & 0.49 & 0.60 & 0.68 & 0.69 & 0.78 \\
\hline
\end{tabular}

Note: The dependent variable is the growth rate of real GDP per capita in local currency. Change in contract enforceability is the change in the logarithm of the contraet enforceability index provided by Levine. The same applies to change in nationalization risk. For both variables, a positive change corresponds to an improvement in the situation. We interacted postlib4all with the average over three years before liberalization of change in contract enforceability and change in nationalization risk respectively. In regressions (i) and (ii), we include four lags of stock market size to captute the independent growth effects of lags in stock market size, which is necessary to interpret the interaction effect. Similarly, in regressions (iii) and (iv), we include four lags of change in contract enforceability, and in regressions ( $v$ ) and (vi) we include four lags of change in nationalization risk. All regressions include country fixed effects and year dummies. Due to data availability, the samples differ between the regressions. Regression (i) includes 25 countries and 22 observations, regression (ii) 25 courtries and 20 observations, regressions (iii) - (vi) 22 countries and 16 observations. 
Regression (i) shows that, as in the growth regressions above, a large stock market as captured by a high market capitalization ratio, seems to have an independent positive growth effect. Additionally, a high market capitalization ratio in the year before liberalization reinforces the positive effect of liberalization on economic growth, as can be seen by the positive and significant coefficient on the interaction variable. This might reflect the fact that foreign investors seem more inclined to invest in stock markets of a certain size. The coefficient remains significant if we include the controls for other economic reforms in regression (ii). Indeed, by including the interaction variable, the independent growth effect of stock market liberalization becomes insignificant. Hence, it seems that for liberalization to have a positive effect on growth, it is crucial for the stock market to have already reached a certain size when liberalization occurs.

In an environment in which the institutional framework is still underdeveloped, credible progress toward an improved framework may have important beneficial side effects. In our study, we found the most significant institutional variables for the success of liberalization to be contract enforceability and nationalization risk. If contract enforceability improves on average during the three years before liberalization, then the growth effect of liberalization is significantly greater, as can be seen in the highly significant coefficient on the interaction variable in column (iv). An improvement in nationalization risk shows similar effects, but these effects are somewhat less significant than are those of improvements in contract enforceability. Results indicate that investors seem to be more attracted to stock markets in countries that are already enhancing their legal frameworks for conducting business. Thus, countries with a poor institutional framework may consider improving their legal frameworks first before concentrating on liberalization of their stock market. Nonetheless, the independent growth effect of stock market liberalization remains significant in both cases. This may suggest that the institutional standard in countries of our sample, though perhaps uneven, was high enough to attract intemational investors.

In studying the effects of other institutional variables, we found that most of the coefficients were not significant. The existence of laws prohibiting insider trading was the only other institutional indicator that showed a positive influence on the growth effect of liberalization, but the coefficient was only significant at the 15 percent level.

The exchange rate system is one of the few macroeconomic variables that seem to have a significant joint effect, along with liberalization, on GDP growth. Our regressions indicate that the positive growth effect of a liberalization on GDP is higher in countries whose exchange rate is pegged. Foreign investors appear to prefer to invest in countries with fixed exchange rate regimes to avoid exchange rate risk. Such an explanation is only valid if the peg is indeed credible and stable, which is often not the case. Thus, one needs to be cautious in drawing any conclusion from this result. Almost all of the liberalizations in our sample occurred before the Mexican, Asian, and Russian currency crises broke out in the second half of the 1990s. Today investors view fixed exchange rate systems more warily, and the credibility of these systems may be much lower. 
As a general conclusion, it seems that the positive growth effects of stock market liberalization can be enhanced if liberalization is preceded by institutional reforms. However, it has been more difficult to empirically establish significant results with respect to macroeconomic preconditions. An important reason could be that in almost all countries stock market liberalizations were preceded or accompanied by stabilization and trade reforms.

\section{G. Liberalization Effect or Comprehensive Reforms?}

One of the major caveats of our study is the fact that stock market liberalizations are often part of larger economic reforms. Thus, the measured effects may still in part reflect the outcome of other reform efforts, although we try to control for these. As we have shown, it seems that reform preconditions differed particularly in Asia and Latin America. Whereas reforms in Asia may have been implemented gradually, in Latin America major economic reforms took place simultaneously with stock market liberalization. Hence, to make our growth results more robust, we look at the growth effects in Asia and Latin America separately, two regions for which we do have a large enough sample.

In Appendix IV, we show the development of financial and real variables around the time of stock market liberalizations separately for Asian and Latin American countries. The development of the variables often differs quite a bit for both regions. While the stock market variables always show some improvement in both regions after liberalization, it is most striking that the real growth effect seems to be almost absent for Asia. This might indicate that the positive growth effects detected above is simply due to broader reforms in Latin American countries. Hence, we redo the last two specifications of the growth regression separately for the Asian and Latin American countries (Table 8).

The liberalization effects are significant in both subsamples. The lower level of significance may reflect the smaller sample size. The growth effects in Asia are much smaller than the effects measured for Latin America. While the mean GDP growth in the third year after liberalization is more than 4 percentage points higher in Latin America, it is only 0.6 percentage points higher in Asia after controlling for other contemporaneous reforms. Thus, it might be true that the large growth effects for Latin America are partly driven by broader economic reforms. Stock market liberalization seems to create a positive growth effect, and even a growth effect of 0.6 percentage points can be significant for a country. 
Table 8. Liberalization: Impact in Asia and Latin America

\begin{tabular}{|c|c|c|c|c|}
\hline & $\begin{array}{l}\text { Asia } \\
\text { (ii) }\end{array}$ & $\begin{array}{l}\text { Asia } \\
\text { (iii) }\end{array}$ & $\begin{array}{l}\text { Latin America } \\
\text { (ii) }\end{array}$ & $\begin{array}{l}\text { Latin America } \\
\text { (iii) }\end{array}$ \\
\hline Lib & $\begin{array}{l}0.0186^{* * *} \\
(0.0056) \\
(0.001)\end{array}$ & $\begin{array}{l}0.0151^{* * *} \\
(0.0046) \\
(0.001)\end{array}$ & $\begin{array}{l}0.0134 \\
(0.0265) \\
(0.614)\end{array}$ & $\begin{array}{l}0.0205 \\
(0.0188) \\
(0.278)\end{array}$ \\
\hline Postlib1 & $\begin{array}{l}0.0128^{* * *} \\
(0.0045) \\
(0.005)\end{array}$ & $\begin{array}{l}-0.0003 \\
(0.0047) \\
(0.949)\end{array}$ & $\begin{array}{l}0.0187 \\
(0.0196) \\
(0.342)\end{array}$ & $\begin{array}{l}0.0222 \\
(0.0161) \\
(0.171)\end{array}$ \\
\hline Postlib2 & $\begin{array}{l}0.0085^{* *} \\
(0.0038) \\
(0.026)\end{array}$ & $\begin{array}{l}0.0001 \\
(0.0037) \\
(0.973)\end{array}$ & $\begin{array}{l}0.0406^{*} \\
(0.0213) \\
(0.059)\end{array}$ & $\begin{array}{l}0.0420^{*} \\
(0.0215) \\
(0.053)\end{array}$ \\
\hline Postlib3 & $\begin{array}{l}0.0145^{* * *} \\
(0.0036) \\
(0.000)\end{array}$ & $\begin{array}{l}0.0061 * \\
(0.0036) \\
(0.092)\end{array}$ & $\begin{array}{l}0.0450^{* *} \\
(0.0228) \\
(0.050)\end{array}$ & $\begin{array}{l}0.0408^{*} \\
(0.0210) \\
(0.054)\end{array}$ \\
\hline Postlib4 & $\begin{array}{l}0.0138 * * * \\
(0.0040) \\
(0.001)\end{array}$ & $\begin{array}{l}0.0050 \\
(0.0038) \\
(0.196)\end{array}$ & $\begin{array}{l}0.0291 \\
(0.0205) \\
(0.159)\end{array}$ & $\begin{array}{l}0.0138 \\
(0.0190) \\
(0.471)\end{array}$ \\
\hline Postlib5 & $\begin{array}{l}0.0086 \\
(0.0053) \\
(0.103)\end{array}$ & $\begin{array}{l}0.0064^{*} \\
(0.0036) \\
(0.074)\end{array}$ & $\begin{array}{l}0.0174 \\
(0.0187) \\
(0.353)\end{array}$ & $\begin{array}{l}0.0119 \\
(0.0186) \\
(0.525)\end{array}$ \\
\hline $1 / Y$ & $\begin{array}{l}0.3026^{* * *} \\
(0.0405) \\
(0.000)\end{array}$ & $\begin{array}{l}0.2697^{* * *} \\
(0.0462) \\
(0.000)\end{array}$ & $\begin{array}{l}0.2170^{*} \\
(0.1147) \\
(0.061)\end{array}$ & $\begin{array}{l}0.3379^{* *} \\
(0.1394) \\
(0.017)\end{array}$ \\
\hline Population growth & $\begin{array}{l}-0.6163^{* *} \\
(0.3058) \\
(0.045)\end{array}$ & $\begin{array}{l}-0.3854 \\
(0.2943) \\
(0.192)\end{array}$ & $\begin{array}{l}-0.1705 \\
(0.2825) \\
(0.547)\end{array}$ & $\begin{array}{l}-0.0971 \\
(0.2221) \\
(0.663)\end{array}$ \\
\hline Illiteracy & $\begin{array}{l}0.0002 \\
(0.0003) \\
(0.589)\end{array}$ & $\begin{array}{l}-0.0002 \\
(0.0004) \\
(0.662)\end{array}$ & $\begin{array}{l}0.0090 \\
(0.0072) \\
(0.211)\end{array}$ & $\begin{array}{l}0.0038 \\
(0.0095) \\
(0.690)\end{array}$ \\
\hline Stock market size & $\begin{array}{l}0.0013 \\
(0.0023) \\
(0.564)\end{array}$ & $\begin{array}{l}0.0059^{* * *} \\
(0.0014) \\
(0.000)\end{array}$ & $\begin{array}{l}0.0136^{*} \\
(0.0078) \\
(0.084)\end{array}$ & $\begin{array}{l}0.0099 \\
(0.0076) \\
(0.199)\end{array}$ \\
\hline Trade openness & & $\begin{array}{l}0.0074 \\
(0.0257) \\
(0.774)\end{array}$ & & $\begin{array}{l}0.0357 \\
(0.0689) \\
(0.606)\end{array}$ \\
\hline Inflation & & $\begin{array}{l}-0.1902^{* * *} \\
(0.0593) \\
(0.002)\end{array}$ & & $\begin{array}{l}-0.0159^{* * *} \\
(0.0049) \\
(0.002)\end{array}$ \\
\hline Change in credit rating & & $\begin{array}{l}0.1088 * * \\
(0.0441) \\
(0.015)\end{array}$ & & $\begin{array}{l}0.0689^{*} \\
(0.0384) \\
(0.076)\end{array}$ \\
\hline Adj. $R^{2}$ & 0.41 & 0.63 & 0.31 & 0.42 \\
\hline
\end{tabular}

Note: The dependent variable is the growth rate of real GDP per capita in local curtency. The regressions for Asia include 11 countries with 24 (ii) and 20 (iii) observations respectively, regressions for Latin America include 7 countries with 25 (ii) and 20 (iii) observations respectively. 


\section{Transitory or Permanent Growth Effect?}

Our analysis still faces two interrelated questions. First, is our sample random? Second, is there only a transitory growth effect or is there also a permanent growth effect?

Although our sample includes countries from all continents and with relatively different economic situations, it is still possible that the countries that liberalized their stock markets during the last two decades shared some other common characteristics. In this case, inference and policy recommendations for countries that have not yet liberalized their stock markets might prove deceptive.

Also, in all of our empirical analyses it appears that the real growth effect diminishes after the fourth year. A permanent growth effect may not have shown up because some countries only liberalized in the 1990 s, thus having too short a post-liberalization period to indicate permanent effects. Results may change in a sample that includes both countries that were already liberalized before our observation period and countries that are not yet integrated into world markets.

Hence, we look at these issues in a larger sample. We recur to the sample from Bekaert, Harvey, and Lundblad (2001), since for these countries they provide information about the liberalization of the stock market. Apart from the 27 countries in our analysis, there are 51 countries that have not yet liberalized their stock markets and 18 countries whose stock markets were already liberalized during the sample period.

To address the first question and to see whether our previous results are confirmed, Table 9 presents in column (i) our standard growth regression, which includes only liberalization dummies, and column (ii), which shows the results with our standard controls. If we only include liberalization dummies, the magnitude of the effects during the first four years is very similar to those found in our smaller sample (see Table 6). However, in the larger sample the effects remain significant in the fourth and fifth years. Although the liberalization effect is getting smaller, this finding hints at a longer-term or even a permanent effect. If we include the most common explanatory variables, as well as our standard controls, the

liberalization effect becomes somewhat smaller, and at the same time the liberalization effect is no longer significant in the third and fourth year after liberalization. So far, all our estimations included country fixed effects and year dummies. To further test the robustness of our results, we re-estimate the equation without country-fixed effects but include initial GDP as control variable (iii). Again, the magnitude and the significance of the liberalization effect are comparable.

So far, we have made no distinction between countries whose stock markets were always liberalized and those whose stock markets were never liberalized. To make this distinction, we now construct a general liberalization dummy, Liball, that takes on the value of 1 throughout the whole observation period for countries that were always liberalized. For countries that are not liberalized it takes on the value of 0 . The 27 countries in our sample, Liball gets a value of 1 for the year of the liberalization and the whole period thereafter. The 
Table 9. Liberalization: Large Sample

\begin{tabular}{|c|c|c|c|c|c|}
\hline & (i) & (ii) & (iii) & (iv) & (v) \\
\hline Liball & & & & $\begin{array}{l}0.0063^{* * *} \\
(0.0012) \\
(0.000)\end{array}$ & $\begin{array}{l}0.0042^{* * * *} \\
(0.0013) \\
(0.001)\end{array}$ \\
\hline Lib & $\begin{array}{l}0.0122^{* * *} \\
(0.0024) \\
(0.000)\end{array}$ & $\begin{array}{l}0.0117^{* * * *} \\
(0.0031) \\
(0.000)\end{array}$ & $\begin{array}{l}0.0112^{* * *} \\
(0.0033) \\
(0.001)\end{array}$ & & $\begin{array}{l}0.0076^{* *} \\
(0.0033) \\
(0.021)\end{array}$ \\
\hline Postlibl & $\begin{array}{l}0.0101 * * * \\
(0.0025) \\
(0.000)\end{array}$ & $\begin{array}{l}0.0062^{* *} \\
(0.0028) \\
(0.025)\end{array}$ & $\begin{array}{l}0.0079^{* * * *} \\
(0.0028) \\
(0.006)\end{array}$ & & $\begin{array}{l}0.0047^{*} \\
(0.0028) \\
(0.092)\end{array}$ \\
\hline Postlib2 & $\begin{array}{l}0.0192^{* * *} \\
(0.0021) \\
(0.000)\end{array}$ & $\begin{array}{l}0.0087^{* * *} \\
(0.0030) \\
(0.003)\end{array}$ & $\begin{array}{l}0.0119 * * * \\
(0.0029) \\
(0.000)\end{array}$ & & $\begin{array}{l}0.0086^{* * *} \\
(0.0030) \\
(0.004)\end{array}$ \\
\hline Postlib3 & $\begin{array}{l}0.0187^{* * * *} \\
(0.0022) \\
(0.000)\end{array}$ & $\begin{array}{l}0.0083^{* * *} \\
(0.0025) \\
(0.001)\end{array}$ & $\begin{array}{l}0.0124^{* * *} \\
(0.0027) \\
(0.000)\end{array}$ & & $\begin{array}{l}0.0093^{* * *} \\
(0.0027) \\
(0.001)\end{array}$ \\
\hline Postlib4 & $\begin{array}{l}0.0087^{* * *} \\
(0.0021) \\
(0.000)\end{array}$ & $\begin{array}{l}0.0012 \\
(0.0021) \\
(0.574)\end{array}$ & $\begin{array}{l}0.0021 \\
(0.0023) \\
(0.366)\end{array}$ & & $\begin{array}{l}-0.0087 \\
(0.0023) \\
(0.703)\end{array}$ \\
\hline Postlib5 & $\begin{array}{l}0.0049^{* *} \\
(0.0021) \\
(0.018)\end{array}$ & $\begin{array}{l}-0.0003 \\
(0.0027) \\
(0.916)\end{array}$ & $\begin{array}{l}0.0008 \\
(0.0023) \\
(0.730)\end{array}$ & & $\begin{array}{l}-0.0021 \\
(0.0024) \\
(0.385)\end{array}$ \\
\hline Initial GDP & & & $\begin{array}{l}-0.0025^{* * *} \\
(0.0003) \\
(0.000)\end{array}$ & $\begin{array}{l}-0.0068^{* * * *} \\
(0.0007) \\
(0.000)\end{array}$ & $\begin{array}{l}-0.0060^{* * *} \\
(0.0008) \\
(0.000)\end{array}$ \\
\hline $\mathrm{I} / \mathrm{Y}$ & & $\begin{array}{l}0.1543^{* * *} \\
(0.0241) \\
(0.000)\end{array}$ & $\begin{array}{l}0.1776^{* * *} \\
(0.0097) \\
(0.000)\end{array}$ & $\begin{array}{l}0.1486^{* * *} \\
(0.0114) \\
(0.000)\end{array}$ & $\begin{array}{l}0.1491^{* * *} \\
(0.0114) \\
(0.000)\end{array}$ \\
\hline Population growth & & $\begin{array}{l}-0.6620^{* * * k} \\
(0.1651) \\
(0.000)\end{array}$ & $\begin{array}{l}-0.4907^{* * *} \\
(0.0720) \\
(0.000)\end{array}$ & $\begin{array}{l}-0.5884^{* * *} \\
(0.0940) \\
(0.000)\end{array}$ & $\begin{array}{l}-0.5949 * * * \\
(0.0932) \\
(0.000)\end{array}$ \\
\hline Stock market size & & $\begin{array}{l}0.0056^{* * *} \\
(0.0011) \\
(0.000)\end{array}$ & $\begin{array}{l}0.0017^{* * *} \\
(0.0004) \\
(0.000)\end{array}$ & $\begin{array}{l}0.0019^{* * *} \\
(0.0003) \\
(0.000)\end{array}$ & $\begin{array}{l}0.0019^{* * *} \\
(0.0029) \\
(0.000)\end{array}$ \\
\hline Trade openness & & $\begin{array}{l}0.0251 * * \\
(0.0121) \\
(0.039)\end{array}$ & $\begin{array}{l}0.0044^{* * *} \\
(0.0011) \\
(0.000)\end{array}$ & $\begin{array}{l}0.0056^{* * *} \\
(0.0013) \\
(0.000)\end{array}$ & $\begin{array}{l}0.0055^{* * *} \\
(0.0013) \\
(0.000)\end{array}$ \\
\hline Inflation & & $\begin{array}{l}-0.0013^{* *} \\
(0.0005) \\
(0.012)\end{array}$ & $\begin{array}{l}-0.0014^{* * *} \\
(0.0005) \\
(0.003)\end{array}$ & $\begin{array}{l}-0.0012 * * * \\
(0.0004) \\
(0.006)\end{array}$ & $\begin{array}{l}-0.0013^{* * *} \\
(0.0004) \\
(0.003)\end{array}$ \\
\hline Change in credit rating & & $\begin{array}{l}0.1227^{* * *} \\
(0.0144) \\
(0.000)\end{array}$ & $\begin{array}{l}0.1183^{* * *} \\
(0.0140) \\
(0.000)\end{array}$ & $\begin{array}{l}0.1289 * * * \\
(0.0133) \\
(0.000)\end{array}$ & $\begin{array}{l}0.1228 * * * \\
(0.0136) \\
(0.000)\end{array}$ \\
\hline Adj. $R^{2}$ & 0.36 & 0.54 & 0.44 & 0.45 & 0.45 \\
\hline
\end{tabular}

Note: The dependent variable is the growth rate of real GDP per capita in local currency. All regressions inciude year durnmies. Regressions (i) and (ii) include fixed effects, regressions (iii) - (v) do not. The sample for regression (i) comprises 96 countries and 25 observations. The sample for regressions (ii) to (v) comprises 72 countries and 20 observations. Liball is a dummy variable that takes on the value of 1 in the year of liberalization and all following years, and 0 otherwise. We omit illiteracy as an explanatory variable, since it would reduce the sample to only 54 countries. Even with the inclusion of illiteracy the results remain unchanged. 
coefficient on Liball is significant at the one percent level, suggesting that there is indeed a permanent growth effect. The signs, magnitude, and significance of all other coefficients are comparable to our previous estimate.

To see whether Liball is not only a reflection of the larger transitory effect of our 27 liberalization cases, the final estimation (iv) looks at the dynamics and the permanent effect at the same time. Therefore, we include both the short-term liberalization dummies and the dummy that captures permanent growth effects. The magnitude of the temporary effects remains on the order of 1 percent per annum. The long-run effect decreases slightly to 0.4 percentage points but remains highly significant.

Finally, a number of sensitivity analyses lend support to this finding. Results are robust to changes in the set of explanatory variables. For example, when we include illiteracy or exclude stock market development and change in credit rating the liberalization coefficient remains highly significant on the order of $0.3-0.5$ percent. Also, including the growth rate of the stock market size (see Table 6) drives out an important part of the short-run impact of liberalization but hardly affected the long-run impact. Overall, our results suggest that stock market liberalizations lead to an important transitory growth effect but also to a smaller permanent growth effect.

\section{Tentative Policy Conclusions}

This paper aims at analyzing the financial and macroeconomic implications of stock market liberalizations. Allowing foreigners to invest in domestic markets is an important policy option that may promote domestic developments. Our empirical findings suggest that the liberalization of a stock market may indeed be an important element in promoting domestic financial markets and general economic development. Results lend support to fundamental findings of the few existing empirical studies but appear to present a more coherent picture of the channels as well as the magnitude of the liberalization effects. The main conclusions are the following:

- Stock market liberalization has a first order impact on the size and liquidity of the domestic stock market and produces noticeable real effects. Even with our most conservative estimates, real private investment growth rises by 6 percentage points in the second year after liberalization and cumulatively by about 14 percentage points in the four years following liberalization. Liberalization is also associated with a rise in real per capita GDP growth on average of about 1 percent during the first four years after the liberalization. The magnitude of this effect is comparable to the one found in Bekaert, Harvey, Lundblad $(2000,2001)$. In contrast to previous analyses, we also provide evidence for a permanent growth effect of about 0.4 percent per annum. The main results are robust with respect to a number of sensitivity analyses. 
- The timing and the dimensions of financial and real effects deliver a consistent picture. It appears plausible that the short-run effects of stock market liberalization on stock market development occur immediately and are rather big. The short-run effects on real private investment and GDP growth take place with a lag and peak in the second and third year after liberalization, respectively. The temporary effect on growth is substantially larger than the long-run effect.

- $\quad$ Stock market development and private investment appear to be two important and interrelated channels through which liberalization enhances real growth. Stock market development facilitates private investment, which in turn stimulates growth. Though we are not able to identify the sources of the permanent effect, this finding is consistent with other analyses that argue that financial liberalization leads to more efficient investments and that financial liberalization boosts productivity growth (Levine, 2001).

- There are cross-country differences as to the impact of stock market liberalization on economic development. The positive growth effects of stock market liberalization tend to be larger if institutional reforms have been implemented prior to liberalization, that is, the institutional framework has improved in the pre-liberalization period. Both a legal framework that allows for better contract enforceability and a lower risk of nationalization are associated with larger positive growth effects. The positive effects of liberalization are also amplified if the stock market already exhibits a certain size, as measured by the market capitalization ratio, at the time of liberalization.

Although results indicate that the positive correlation between real GDP growth per capita and stock market liberalization is robust to a number of potential omitted variables, it is worth repeating a number of caveats. We explicitly include a number of proxies to capture other reform efforts, but certain reform elements may still not be fully captured. Also, the econometric specifications are more a description of the data than the outcome of a tightly specified theory. In addition, we only analyze one policy measure to obtain access to international capital. We start from the assumption that domestic stock markets exist and that they can be liberalized. In the current fast changing financial environment it is open to debate whether each country needs its own stock exchange or whether these services cannot be imported more efficiently, for example, through a listing at a regional exchange or elsewhere. However, this will most likely also require a political decision to let foreigners hold domestic stocks. Therefore, the fundamental, underlying results of our analysis still apply. 


\section{Data Sources}

\section{Emerging Market Data Base}

- Number of listed companies

- Market capitalization in national currency

- Turnover ratio (for Japan and Spain from FIBV webpage)

\section{International Financial Statistics}

- Population (for Taiwan, Province of China, from WEO)

- Gross fixed capital formation

- Changes in inventories in national currency

\section{World Economic Outlook}

- Exports of goods and services

- Imports of goods and services

- Nominal GDP

- Terms of trade

- GDP deflator and consumer price index

- Real GDP per capita in national currency

- Gross fixed capital formation (for Taiwan (China) and large sample)

- Gross private fixed capital formation

- Changes in inventories in national currency (for Taiwan (China) and large sample)

\section{World Development Indicators}

- Illiteracy in percent among young adults (15-24 years)

- Private investment in percent of gross domestic fixed investment

- Gross domestic fixed investment

- Private credit in percent of GDP

- Number of listed companies (for Spain, Japan, and large sample)

- Market capitalization in percent of GDP (for large sample)

- Inflation based on CPI in percent per year (for large sample)

\section{Other sources}

- Country credit rating taken: information taken from Institutional Investor. We thank Utpal Bhattacharya for providing us with his data set.

- Contract enforceability and nationalization risk: we thank Ross Levine for providing us with his data set. 
- Dummy variable for fixed exchange rate systern: information taken from IMF Exchange Arrangements and Exchange Restrictions; we thank Benoit Mercereau for providing us with his data set.

- Dummy for insider trading law: information taken from dataset by Levine, Loayza and Beck. 


\section{Stock Market Liberalizations: Comparing Liberalization Dates}

\begin{tabular}{|c|c|c|c|c|c|c|}
\hline & $\begin{array}{l}\text { Henry } \\
(2000)\end{array}$ & $\begin{array}{c}\mathrm{Kim} / \\
\text { Singal (2000) }\end{array}$ & $\begin{array}{c}\text { Bekaert } \\
\text { Harvey } \\
(2000)\end{array}$ & $\begin{array}{c}\text { Bekaert/ } \\
\text { Harvey/ } \\
\text { Lundblad } \\
(2001)^{*}\end{array}$ & $\begin{array}{l}\text { Bhattacharya/ } \\
\text { Daouk (2001) }\end{array}$ & This study \\
\hline Argentina & $11 / 89$ & $11 / 89$ & $11 / 89$ & $11 / 89$ & $11 / 89$ & $11 / 89$ \\
\hline Brazil & $03 / 88$ & $05 / 91$ & $05 / 91$ & $05 / 91$ & $05 / 91$ & $05 / 91$ \\
\hline Chile & $05 / 87$ & $10 / 89$ & $01 / 92$ & $01 / 92$ & $01 / 92$ & $01 / 92$ \\
\hline Colombia & $12 / 91$ & $02 / 91$ & $02 / 91$ & $02 / 91$ & $02 / 91$ & $02 / 91$ \\
\hline Egypt & & & & 97 & & $09 / 93$ \\
\hline Greece & & $08 / 86$ & $12 / 87$ & $12 / 87$ & $12 / 87$ & $08 / 86$ \\
\hline India & $06 / 86$ & $11 / 92$ & $11 / 92$ & $11 / 92$ & $11 / 92$ & $11 / 92$ \\
\hline Indonesia & & $09 / 89$ & $09 / 89$ & $09 / 89$ & $09 / 89$ & $09 / 89$ \\
\hline Japan & & & & 83 & $12 / 80$ & $12 / 80$ \\
\hline Jordan & & $01 / 78$ & $12 / 95$ & $12 / 95$ & $12 / 95$ & $12 / 95$ \\
\hline Korea & $06 / 87$ & $01 / 92$ & $01 / 92$ & $01 / 92$ & $01 / 92$ & $01 / 92$ \\
\hline Malaysia & $05 / 87$ & Before $12 / 75$ & $12 / 88$ & $12 / 88$ & $12 / 88$ & $12 / 88$ \\
\hline Mexico & $05 / 89$ & $05 / 89$ & $05 / 89$ & $05 / 89$ & $05 / 89$ & $05 / 89$ \\
\hline Morocco & & & & 97 & & $04 / 94$ \\
\hline Nigeria & & Still closed & $08 / 95$ & $08 / 95$ & $08 / 95$ & $08 / 95$ \\
\hline Pakistan & & $02 / 91$ & $02 / 91$ & $02 / 91$ & $02 / 91$ & $02 / 91$ \\
\hline Peru & & & & & & $11 / 91$ \\
\hline Philippines & $05 / 86$ & $03 / 86$ & $06 / 91$ & $06 / 91$ & $06 / 91$ & $06 / 91$ \\
\hline Portugal & & $07 / 86$ & $07 / 86$ & $07 / 86$ & $07 / 86$ & $07 / 86$ \\
\hline South Africa & & & & 92 & & $03 / 95$ \\
\hline Spain & & & & 85 & $01 / 78$ & $05 / 85$ \\
\hline Sri Lanka & & & & 92 & & 1990 \\
\hline Taiwan & $05 / 86$ & $01 / 91$ & $01 / 91$ & $01 / 91$ & $01 / 91$ & $01 / 91$ \\
\hline Thailand & $01 / 88$ & $08 / 88$ & $09 / 87$ & $09 / 87$ & $09 / 87$ & $09 / 87$ \\
\hline Turkey & & $08 / 89$ & $08 / 89$ & $08 / 89$ & $08 / 89$ & $08 / 89$ \\
\hline Venezuela & $01 / 90$ & $01 / 90$ & $01 / 90$ & $01 / 90$ & $01 / 90$ & $01 / 90$ \\
\hline Zimbabwe & & $07 / 93$ & $06 / 93$ & $06 / 93$ & $06 / 93$ & $06 / 93$ \\
\hline
\end{tabular}

See for a description of major financial developments the chronology of Bekaert and Harvey at:

http://www.duke.edw/ charyev/Country risk/chronology/. For those countries for which no information or only limited information was given, supplementary information is given below.

* Includes only countries listed that are in sample IV and did not liberalize before 1980 (which are the countries that are always liberalized in the sample)

\section{Egypt}

Law 95 of 1992 gives foreign investors full access to the capital market, also allowing establishment of Egyptian and foretgn security companies to conduct underwriting of subscriptions, brokerage, managing securities portfolios and mutual funds, clearing and settling of securities, and venture capital activities (information provided by Tradeport, an international trade/defense conversion initiative managed by the Bay Area Economic Forum and the Los Angeles Area Chamber of Commerce)

Israel

Israel is in the sample of Bekaert, Harvey, and Lundblad with liberalization date 1996; yet several sources, including the Israeli Ministry of Finance and the IMF Exchange Arrangements and Exchange Restrictions, confirmed that liberalization occurred before 1975; hence, Israel is not included into our small sample

Japan

The Foreign Exchange Act of 12/1980 essentially allowed foreign ownership of Japanese shares; however, holdings of 10 percent or more required an examination carried out by the Ministry of Finance, a measure which was abolished in 1984 
(still certain restrictions of ownership apply for specific entities, e.g., airlines, national broadcasters); this information was provided by the Tokyo Stock Exchange and confirmed by Gultekin, Gultekin, and Penati (1989) and Ito (1992)

\section{Morocco}

First international investment fund allowed to be centered entirely on investment in the Moroccan market established by Salomon Brothers Inc. of the U.S. and Omnium Nord African (ONA) of Morocco in 4/94 (information provided by National U.S.-Arab Chamber of Commerce); also, EIU reports the stock market as 100 percent open to foreigners already in 1998

\section{Peru}

Major opening of the Lima stock exchange to foreign investment occurred in $11 / 91$ by decree 757 ; decree 662 earlier in 1991 provided some initial steps towards opening (information confirmed by Peruvian government, Lima stock exchange and EIU)

\section{South Africa}

In March 1995, the "financial rand" was abolished; the financial rand had to be used for purchases of securities and repatriation of capital and capital gains by foreigners, and it was traded at a discount to the commercial rand

\section{Spain}

Under measures announced in $05 / 85$, as a general principle government authorization will no longer be necessary for foreign investment in either equity or real estate; complete freedom to repatriate capital, capital gains and dividends on investments made since 1959 has been granted (EIU Country Report)

\section{Sri Lanka}

Until the summer of 1990 , any transaction involving either the purchase of shares by a foreigner or their subsequent sale either to another foreigner or to a Sri Lankan was taxed at a punitive 100 percent rate; the tax was lifted in the summer of 1990 , although a 40 percent limit on the amount of equity that any foreigner can hold in a Sri Lankan company was still in place (information from EIU Country Report 3/1990). 
Stock Market Liberalization: Stylized Development (incl. S.E.)

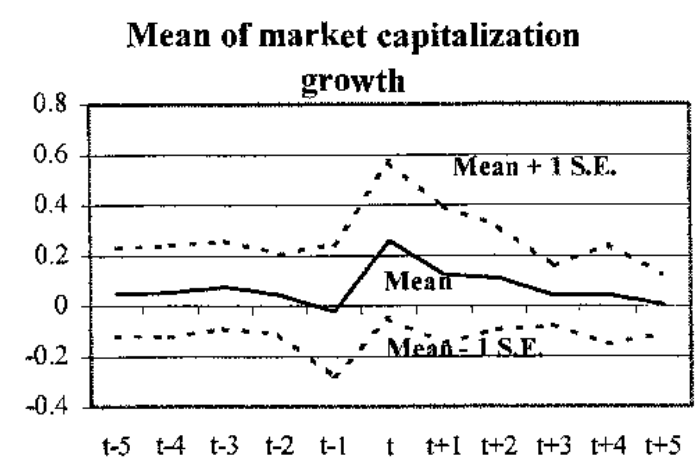

Figure 2a: This figure shows the average growth rate of the ratio of market capitalization to GDP around the time of stock market liberalization ( $t$ ).

Mean growth rate of number of listed companies

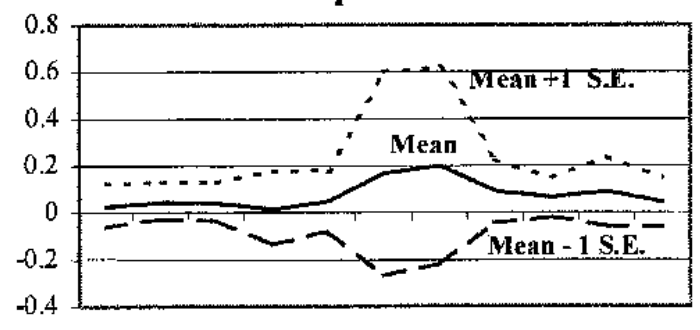

$\begin{array}{lllllllllll}t-5 & t-4 & t-3 & t-2 & t-1 & t & t+1 & t+2 & t+3 & t+4 & t+5\end{array}$

Figure 2c: This figure shows the average growth rate of the number of listed companies around the time of stock market liberalization (t).

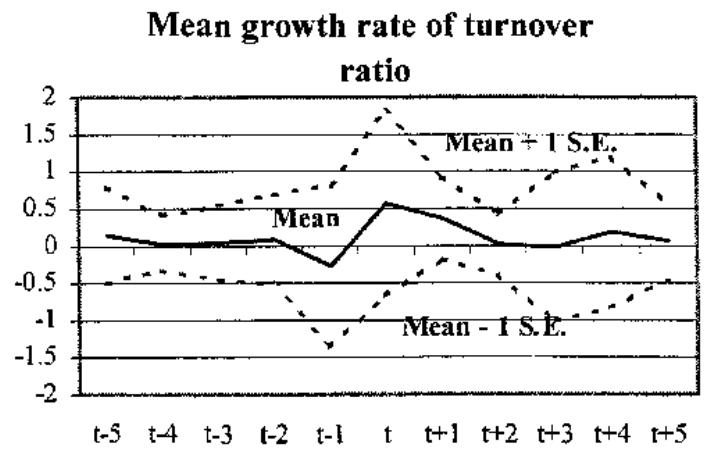

Figure 2b: This figure shows the average growth rate of the turnover ratio around the time of stock market liberalization (t).

Mean growth rate of real private investment

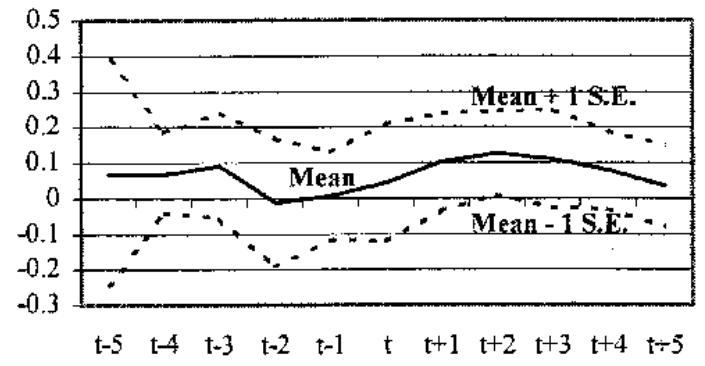

Figure 2d: This figure shows the average growth rate of real private investment around the time of stock market liberalization $(t)$. 
Financial and Economic Development by Region

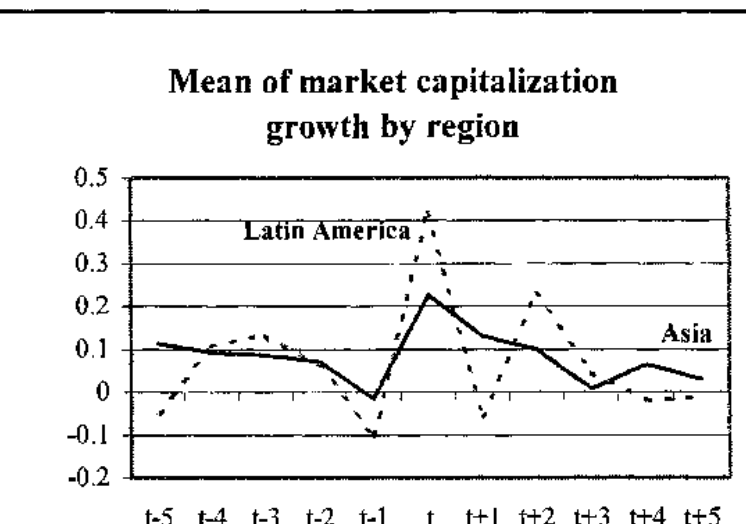

Figure 3a: This figure shows the average growth rate of the ratio of market capitalization to GDP around the time of stock market liberalization ( $t$ ).

Mean growth rate of number of listed companies by region

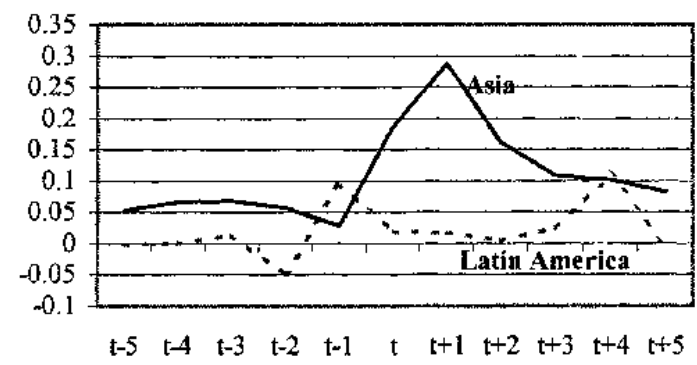

Figure $3 \mathrm{c}$ : This figure shows the average growth rate of the number of listed companies around the time of stock market liberalization $(t)$.

\section{Mean growth rate of real per capita GDP}

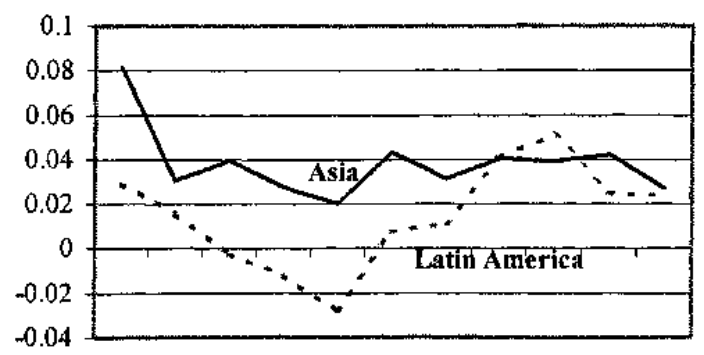

$t-5 \quad t-4 \quad t-3 \quad t-2 \quad t-1 \quad t \quad t+1 \quad t+2 \quad t+3 \quad t+4 \quad t+5$

Figure 3e: This figure shows the average growth rate of real per capita GDP around the time of stick market liberalization $(t)$.

\section{Mean growth rate of turnover ratio by region}

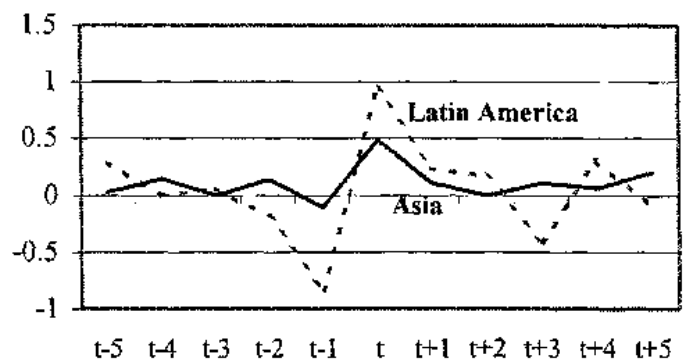

Figure $3 \mathrm{~b}$ : This figure shows the average growth rate of the turnover ratio around the time of stock market liberalization ( $t$ ).

\section{Mean growth rate of real private} investment by region

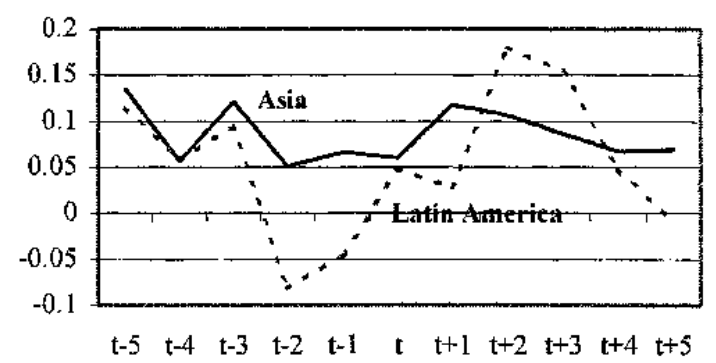

Figure 3d: This figure shows the average growth rate of real private investment around the time of stock market liberalization $(\mathrm{t})$. 


\section{REFERENCES}

Atje, Raymond, and Boyan Jovanovic, 1993, "Stock Markets and Development," European Economic Review, Vol. 37, pp. 632-640.

Barro, Robert J., 1997, "Determinants of Economic Growth: A Cross-Country Empirical Study, (Cambridge, Massachusetts: MIT Press).

Bhattacharya, Utpal, and Hazem Daouk, 2001, "The World Price of Insider Trading" (unpublished: Bloomington, Indiana: University of Indiana).

Beck, Thorsten, and Ross Levine, 2001, "Stock Markets, Banks, and Growth: Correlation or Causality," mimeo, July.

Beck, Thorsten, Ross Levine and Norman Loayza, 2000, "Finance and the Sources of Growth," Journal of Financial Economics, Vol. 58, No. 1, pp. 261-300.

Bekaert, Geert, and Campbell R. Harvey, 2000, "Foreign Speculators and Emerging Equity Markets," Journal of Finance, Vol. 55 (April), pp. 565-613.

— 2000, "Emerging Equity Markets and Economic Development," NBER Working Paper 7763 (June) (Cambridge, Massachusetts: National Bureau of Economic Research).

Bekaert, Geert, Campbell R. Harvey and Christian Lundblad, 2001, "Does Financial Liberalization Spur Growth?" NBER Working Paper 8245 (April) (Cambridge, Massachusetts: National Bureau of Economic Research).

Bencivenga, Valerie R., Bruce D. Smith, and Ross M. Starr, 1995, "Transaction Costs, Technological Choice and Endogenous Growth," Journal of Economic Theory, Vol. 67 (October), pp. 53-77.

Boot, Arnoud W.A., and Anjan Thakor, 1997, "Financial System Architecture," Review of Financial Studies, Vol. 10 (July), pp. 693-733.

Claessens, Stijn, Simeon Djankov, and Daniela Klingebiel, 2000, Stock Markets in Transition Economies, Financial Sector Discussion Paper No. 5 (Washington: World Bank).

Demirgüc-Kunt, A. and Ross Levine, 1996, "Stock Market Development and Financial Intermediaries: Stylised Facts," World Bank Economic Review, Vol. 10 (May), pp. 291-321.

Devereux, Michael B. and Gregor W. Smith, 1994, "International Risk Sharing and Economic Growth," International Economic Review, Vol. 35 (August), pp. 535-550. 
Economist Intelligence Unit, Country Reports, Various issues, various years.

Edison, Hali. J. and Francis E. Warnock, 2001, "A Simple Measure of the Intensity of Capital Controls," International Finance Discussion Papers No. 708, September (Washington: Board of Governors of the Federal Reserve System).

Funke, Norbert, 1993, "Timing and Sequencing of Reforms: Competing Views and the Role of Credibility," Kyklos, Vol. 46, No. 3, pp. 337-362.

Gultekin, Mustafa N., N. Bulent Gultekin, and Alessandro Penati, 1989, "Capital Controls and International Capital Market Segmentation: The Evidence from the Japanese and American Stock Markets," Journal of Finance, Vol. 44 (September), pp. 849-869.

Haque, Nadeem.U., M. Hashem Pesaran and Sunil Sharma, 1999, "Neglected Heterogeneity and Dynamics in Cross-Savings Regressions," DAE Working Paper 9904, January (Cambridge: Cambridge University).

Hansen, Henrik, and Finn Tarp, 2001, "Aid and Growth Regressions", Journal of Development Economics, Vol. 64, pp. 547-570

Henry, Peter Blair, 2000a, "Stock Market Liberalization, Economic Reform, and Emerging Market Equity Prices, Journal of Finance, Vol. 55 (April), pp. 529-564.

- 2000b, "Do Stock Market Liberalizations Cause Investment Booms," Journal of Financial Economics, Vol. 58, No. 1, pp. 301-334.

Holmstrom, Bengt, and Jean Triole, 1993, "Market Liquidity and Performance Monitoring," Journal of Political Economy, Vol. 101 (August), pp. 678-709.

International Monetary Fund, 2001, "International Financial Integration and Developing Countries" World Economic Outlook, October, Chapter IV, pp. 143-171.

Ito, Takatoshi, 1992, The Japanese Economy (Cambridge, Massachusetts: MIT Press).

Johnston, R. Barry, 1998, "Sequencing Capital Account Liberalizations and Financial Sector Reform," IMF Paper on Policy Analysis and Assessment 98/8 (Washington: International Monetary Fund).

Johnston, R. Barry, and V. Sundararajan, 1999, Sequencing Financial Sector Reforms, (Washington: International Monetary Fund).

Khan, Mohsin S., and Abdelhak S. Senhadji, 2000, "Financial Development and Economic Growth: An Overview," IMF Working Paper 00/209 (Washington: International Monetary Fund). 
Kim, E. Han, and Vijay Singal, 2000, "Stock Market Openings: Experience of Emerging Economies," Journal of Business, Vol. 73 (January), pp. 25-66.

King, Robert, and Ross Levine, 1993, "Finance and Growth: Schumpeter Might be Right," Quarterly Journal of Economics, Vol. 108 (August), pp. 717-737.

Levine, Ross, 1997, "Financial Development and Economic Growth: Views and Agenda," Journal of Economic Literature, Vol. 35 (June), pp. 688-726.

-__ 1999, "Financial Development and Growth: Where Do We Stand," Estudios de Economia, Vol. 26 (December), pp. 113-136.

_- 2001, forthcoming, "International Financial Integration and Economic Growth," Review of International Economics.

Levine, Ross, and David Renelt, 1992, "A Sensitivity Analysis of Cross-Country Growth Regressions," American Economic Review, Vol. 82 (September), pp. 942-963.

Levine, Ross, and Sara Zervos, 1998, "Stock Markets, Banks and Economic Growth," American Economic Review, Vol. 88 (June), pp. 537-558.

Nsouli, Saleh, and Mounir Rached, 1998, "Capital Account Liberalization in the Southern Mediterranean Region," IMF Paper on Policy Analysis and Assessment 98/11 (Washington: International Monetary Fund).

Obstfeld, Maurice, 1994, "Risk-Taking, Global Diversification and Growth," American Economic Review, Vol. 84 (December), pp. 1310-1329.

Rousseau, P.L., P. Wachtel, 2000, "Equity Markets and Growth: Cross-Country Evidence On Timing and Outcomes, 1980-1995," Journal of Banking and Finance, Vol. 24 (December), pp. 1933-1957.

Shleifer, Andrei, and Robert W. Vishny, 1986, "Large Shareholders and Corporate Control," Journal of Political Economy, June 1986, Vol. 94 (June), pp. 461-488.

World Bank, 2001, World Development Indicators (Washington). 